\title{
Pengaruh Kualitas Layanan Jasa Pendidikan Terhadap Kepuasan Mahasiswa serta Dampaknya Terhadap Upaya Peningkatan Citra Perguruan Tinggi Negeri Menuju World Class University \\ (Studi pada Mahasiswa Asing di ITB, UNPAD, dan UPI)
}

\author{
Puspo Dewi Dirgantari'
}

\begin{abstract}
Abstrak
Pendidikan merupakan salah satu alat yang yang paling efektif untuk mengubah manusia. Seiring dengan globalisasi yang terus teriadi dengan kecepatan tinggi yang menyentuh setiap aspek kehidupan manusia secara global menyentuh pula pendidikan. Perubahan ini membuat pasar dan persaingan perguruan tinggi menjadi lebih luas dari sebelumnya dan relatif bergerak lebih cepat dibandingkan dengan kemampuan perguruan tinggi untuk meresponnya. Saat ini telah ada pemeringkatan universitas-universitas di dunia yang bertandar internasional yang dilakukan oleh lembaga-lembaga yang diakui oleh dunia, perguruan tinggi di Indonesia tidak termasuk 50 universitas terbaik dunia baik versi Webometrics maupun QS World University Rankings. Hal ini menunjukan bahwa masih lemahnya daya saing perguruan tinggi di Indonesia dibandingkan dengan perguruan tinggi di luar negeri yang pada akhirnya daya saing perguruan tinggi ini akan membangun citra perguruan tingginya. Citra memiliki arti yang sangat penting bagi institusi. Citra adalah sebuah faktor yang penting yang saling berhubungan dengan kepuasan konsumen dan loyalitas. Pengalaman langsung mempunyai pengaruh yang kuat terhadap citra

Metode yang digunakan dalam penelitian ini adalah descriptif survey dan explanatory survey terhadap sampel berukuran 100 orang mahasiswa asing di tiga perguruan tinggi negeri di Bandung yaitu ITB, UNPAD dan UPI. Data yang digunakan adalah data primer dan data sekunder yang dikumpulkan melalui studi kepustakaan dan kuesioner. Sedangkan untuk mengukur besarnya pengaruh kualitas layanan jasa pendidikan terhadap kepuasan mahasiswa serta dampaknya terhadap upaya peningkatan citra perguruan tinggi negeri di Bandung digunakan analisis SEM (Structural Equation Modelling).

Hasil penelitian mengungkapkan bahwa kualitas layanan jasa pendidikan berpengaruh positif terhadap kepuasan mahasiswa dan pengaruh kepuasan mahasiswa berpengaruh positif terhadap citra perguruan tinggi negeri di Bandung. Atribut layanan yang harus diprioritaskan atau yang harus mendapat perhatian lebih atau diperbaiki sehingga kinerjanya meningkat antara lain: asrama mahasiswa, Infrastruktur TI, fasilitas medism, dan potensi-potensi staf seperti etos kerja, fleksibilitas, ketelitian, kedisiplinan, kreatif dan inovasi, integritas dan tanggung jawab.
\end{abstract}

\section{Kata Kunci : Citra Perguruan Tinggi, Kepuasan Mahasiswa, Kualitas Layanan Jasa Pendidikan}

\section{Pendahuluan}

Pendidikan merupakan salah satu alat yang yang paling efektif untuk mengubah manusia, dampak pendidikan dalam pembentukan kualitas manusia dua atau tiga kali lebih kuat dibandingkan dengan yang lain. Pendidikan mengemban tugas untuk meningkatkan kualitas individu supaya lebih produktif, pendidikan bertugas sebagai fungsi pengendali sosial, pelestarian budaya, pusat latihan dan pengembangan tenaga kerja dan pembentukan sikap (Inkeles \& Smith,1974:304).
Keberhasilan suatu bangsa dalam membangun pendidikan juga menjadi barometer tingkat kemajuan bangsa yang bersangkutan (Sumarto, 2002:10). WEF (World Education Forum) melaporkan bahwa dampak positif dari kemajuan pendidikan antara lain dapat dilihat dari semakin baiknya struktur demografik, meningkatnya kualitas kehidupan dan semakin tercapainya pembangunan di berbagai sektor. Oleh karena itu mengingat pentingnya peran pendidikan bagi kemajuan pembangunan sebuah bangsa, maka tidak mengherankan kalau banyak negara 
memberikan prioritas pembangunan di sektor pendidikan ini.

Di Indonesia, upaya dalam pembangunan pendidikan juga dilakukan di berbagai jenjang, mulai pendidikan dasar, menengah sampai pendidikan tinggi. Semua jenjang ini diharapkan meraih fungsi dan tujuan sebagaimana tertuang dalam Undang-Undang Sistem Pendidikan Nasional Nomor 20 Tahun 2003 (Bab II Pasal 3) fungsi dan tujuan pendidikan di Indonesia adalah:

Pendidikan nasional berfungsi mengembangkan kemampuan dan membentuk watak serta peradaban bangsa yang bermartabat dalam rangka mencerdaskan kehidupan bangsa, bertujuan untuk berkembangnya potensi peserta didik agar menjadi manusia yang beriman dan bertakwa kepada Tuhan Yang Maha Esa, berakhlak mulia, sehat, berilmu, cakap, kreatif, mandiri dan menjadi warga Negara yang demokratis serta bertanggung jawab.

Pendidikan tinggi merupakan salah satu pilar penting yang diharapkan dapat membawa perubahan suatu bangsa, karena pendidikan tinggi bersifat melatih orang mempertajam dan menggunakan nalarnya untuk memecahkan persoalan-persoalan yang dihadapinya. Pendidikan tinggi hadir sebagai lingkungan bernalar untuk memanusiakan manusia sesuai dengan citra manusia (Drost, 1990:124)

Pendidikan tinggi adalah pendidikan pada jalur pendidikan sekolah pada jenjang yang lebih tinggi daripada pendidikan menengah di jalur pendidikan sekolah. Sebaliknya perguruan tinggi adalah satuan pendidikan yang menyelenggarakan pendidikan tinggi (Indrajit dan Djokopranoto, 2006:3)

Menurut Undang-Undang Sistem Pendidikan Nasional Nomor 20 Tahun 2003 (Pasal 20 ayat 1), satuan pendidikan yang menyelenggarakan pendidikan tinggi disebut perguruan tinggi yang dapat berbentuk Akademi, Politeknik, Sekolah Tinggi, Institut, atau Universitas, dengan spesifikasi sebagai berikut :

1. Akademi, menyelenggarakan pendidikan vokasi dalam satu cabang atau sebagian cabang ilmu pengetahuan, teknologi, dan/atau seni tertentu.

2. Politeknik, menyelenggarakan pendidikan vokasi dalam sejumlah bidang pengetahuan khusus.
3. Sekolah tinggi, menyelenggarakan pendidikan akademik dan/atau vokasi dalam lingkup satu disiplin ilmu tertentu dan jika memenuhi syarat dapat menyelenggarakan pendidikan profesi.

4. Institusi, menyelenggarakan pendidikan akademi dan/atau pendidikan vokasi dalam sekelompok disiplin ilmu pengetahuan, teknologi, dan/atau seni dan jika memenuhi syarat dapat menyelenggarakan pendidikan profesi.

5. Universitas, menyelenggarakan program pendidikan akademik dan/atau pendidikan vokasi dalam sejumlah ilmu pengetahuan, teknologi, dan/atau seni dan jika memenuhi syarat dapat menyelenggarakan pendidikan profesi.

Seiring dengan globalisasi yang terus terjadi dengan kecepatan tinggi yang menyentuh setiap aspek kehidupan manusia secara global menyentuh pula pendidikan. Pendidikan secara global merupakan infrastruktur pembangunan masyarakat dunia. Globalisasi pendidikan ini menghilangkan batas-batas yang selama ini menghambat perkembangan pendidikan secara global. Globalisasi menerobos dinding geografis, kebangsaan kebudayaan bahkan peradaban bangsa-bangsa, sehingga pendidikan sebagai muatan globalisasi, tidak dapat dicegah lagi oleh negara dan masyarakat dunia manapun.

Perubahan ini membuat pasar dan persaingan perguruan tinggi menjadi lebih luas dari sebelumnya dan relatif bergerak lebih cepat dibandingkan dengan kemampuan perguruan tinggi untuk meresponnya.

Saat ini telah ada pemeringkatan universitasuniversitas di dunia yang bertandar internasional yang dilakukan oleh lembaga-lembaga yang diakui oleh dunia, seperti :

1. Times Higher Education Supplement (THES) dari Inggris. THES menilai berdasarkan empat faktor, yakni kualitas riset, terserapnya lulusan ke dunia kerja, prestasi internasional, serta kualitas pengajaran.

2. QS World University Ranking dari Amerika (US News). Kriteria akademik QS WUR berdasarkan atas kualitas penelitian (academic per review), rasio mahasiswa terhadap staf pengajarnya (student to faculty ratio), hasil penelitian yang dikutip (citations per paper), yaitu seberapa banyak penelitian universitas terkait dikutip, kesiapan lulusan masuk dunia kerja (employer review) 
yaitu sebuah survei untuk memperoleh informasi tentang kesiapan kerja lulusan serta tingkat kepuasannya, jumlah mahasiswa asing (international students) yaitu jumlah mahasiswa internasional, dan international faculty yaitu jumlah dosen yang berasal dari luar negeri yang mengajar di suatu perguruan tinggi.

3. Webometrics Ranking of World Universities, yang bermarkas di Spanyol. Lembaga ini lebih menilai dari aspek akses publikasi ilmiah untuk meningkatkan kehadiran akademik di situs-situs web. Didasarkan pada gabungan indikator yang memperhitungkan volume ataupun isi web, visibilitas, dan dampak dari publikasi web.

4. Academic Ranking of World Universities (ARWU), digagas Universitas Jiao Tong Shanghai, yang merumuskan bobot peringkat lebih ketat, seperti para alumninya adalah pemenang Hadiah Nobel dan penghargaan internasional, para staf pengajarnya memenangi Hadiah Nobel, serta melakukan penelitian yang dikutip dalam 21 kategori subyek luas.

(Sumber: Koran Tempo, 17 April 2010, Menuju Universitas Berkelas Dunia, diakses tanggal 08/07/2011, jam 13.03)

Berikut ini adalah peringkat universitas terbaik di duna tahun 2010 berdasarkan eksistensinya di internet. Berdasarkan 16.000 perguruan tinggi di seluruh dunia yang ikut dinilai, Indonesia menempatkan 26 wakilnya dalam kelompok 5000 besar dunia. Pemeringkatan ini memang hanya mengukur sejauhmana sebuah perguruan tinggi memanfaatkan internet. Penting dicatat, perguruan tinggi-perguruan tinggi terbaik dunia saat ini, juga memiliki ranking webometrics yang sangat baik.

\section{Tabel 1}

\section{Peringkat 1-10 Universitas Terbaik di Dunia Versi Webometrics}

\begin{tabular}{|c|c|c|l|l|c|c|c|c|}
\hline \multicolumn{3}{|c|}{ World Rank } & \multirow{2}{*}{ University } & \multirow{2}{*}{ Country } & \multicolumn{4}{c|}{ Position } \\
\cline { 6 - 8 } & 2009 & 2011 & & Size & Visibility & Rich files & Scholar \\
\hline 1 & 2 & 1 & Massachusetts Institute of Technology & America & 2 & 1 & 3 & 10 \\
\hline 3 & 1 & 2 & Harvard University & America & 7 & 4 & 16 & 1 \\
\hline 2 & 3 & 3 & Stanford University & America & 4 & 3 & 1 & 48 \\
\hline 4 & 4 & 4 & University of California Berkeley & America & 5 & 2 & 6 & 87 \\
\hline 5 & 5 & 5 & Cornell University & America & 1 & 11 & 9 & 50 \\
\hline & 10 & 6 & University of Wisconsin Madison & America & 3 & 5 & 8 & 124 \\
\hline & 9 & 7 & University of Michigan & America & 6 & 7 & 20 & 44 \\
\hline 8 & 7 & 8 & University of Minnesota & America & 13 & 26 & 4 & 16 \\
\hline 6 & 6 & 9 & University of Washington & America & 9 & 17 & 2 & 136 \\
\hline & 14 & 10 & University of Pennsylvania & America & 24 & 12 & 29 & 49 \\
\hline
\end{tabular}

(Sumber: http://www. webometrics. info/top12000.asp, diakses tanggal 15/04/2011, jam 13:59)

Pemeringkatan Webometrics ini didasarkan atas keunggulan dalam publikasi elektronik (e-publication) yang terdapat dalam domain web masing-masing perguruan tinggi. Pengukurannya menggunakan empat indikator, yakni size, visibility, rich files, dan scholar. Indikator pertama, size (S), yakni jumlah halaman publikasi elektronik yang terdapat dalam domain web perguruan tinggi. Kedua, visibility $(\mathrm{V})$ ialah jumlah halaman lain yang mencantumkan URL (Uniform Resource Locator yaitu rangkaian karakter menurut suatu format standar tertentu, yang digunakan untuk menunjukkan alamat suatu sumber seperti dokumen dan gambar di Internet) domain perguruan tinggi yang dinilai. Ketiga, rich files (RF), yaitu relevansi sumber elektronik dengan kegiatan akademik dan publikasi perguruan tinggi tersebut. Terakhir, scholar (Sc), yakni jumlah publikasi dan situasi bermutu pada domain perguruan tinggi. Selanjutnya, data yang telah terkumpul diolah dan digunakan untuk memeringkat perguruan tinggi dari seluruh dunia. 
Tabel 2

Peringkat 1-30 Universitas-Universitas Indonesia di Dunia

Versi Webometrics

\begin{tabular}{|c|c|c|c|c|c|c|c|}
\hline \multicolumn{3}{|c|}{ World Rank } & \multirow{2}{*}{ University } & \multicolumn{4}{|c|}{ Position } \\
\hline 2009 & 2010 & 2011 & & Size & Visibility & Rich files & scholar \\
\hline 562 & 611 & 583 & Universitas Gadjah Mada & 501 & 815 & 1,152 & 71 \\
\hline 815 & 789 & 599 & University of Indonesia & 438 & 969 & 634 & 11 \\
\hline 661 & 569 & 770 & Institute of Technology Bandung & 444 & 908 & 919 & 529 \\
\hline 1628 & 1474 & 1000 & Airlangga University & 1,084 & 1,223 & 521 & 301 \\
\hline 2059 & 1517 & 1004 & Diponegoro University & 558 & 2,477 & 1,78 & 15 \\
\hline 854 & 1117 & 1007 & Petra Christian University & 308 & 2,295 & 802 & 399 \\
\hline 1025 & 813 & 1010 & Gunadarma University & 646 & 1,51 & 686 & 486 \\
\hline & 3229 & 1015 & Andalas University & 2,234 & 1,59 & 639 & 170 \\
\hline 1315 & 1348 & 1017 & Institut Teknologi Sepuluh Nopember & 1,029 & 1,506 & 1,883 & 41 \\
\hline 1256 & 1744 & 1018 & Universitas Negeri Malang * & 1,958 & 1,495 & 1,08 & 83 \\
\hline 2337 & 2087 & 1026 & Universitas Sriwijaya & 971 & 2,444 & 1,314 & 236 \\
\hline 2471 & 2845 & 1041 & Universitas Muhammadiyah Surakarta & 1,647 & 4,34 & 1,952 & 21 \\
\hline 3307 & 2356 & 1056 & Universitas Sumatera Utara & 1,633 & 3,049 & 2,546 & 28 \\
\hline 2162 & 1127 & 1204 & Bogor Agricultural University & 1,83 & 1,075 & 1,53 & 1,204 \\
\hline 2422 & 1724 & 1217 & Universitas Islam Indonesia & 1,565 & 1,707 & 3,556 & 232 \\
\hline 1585 & 1520 & 1253 & Universitas Sebelas Maret & 875 & 1,621 & 1,509 & 1,628 \\
\hline 6405 & 5741 & 1382 & Unikom & 1,845 & 7,698 & 4,173 & 22 \\
\hline 4729 & 2310 & 1395 & Universitas Muhammadiyah Malang & 2,71 & 2,565 & 1,066 & 1,264 \\
\hline 3135 & 2927 & 1831 & Yogyakarta State University & 2,539 & 2,316 & 4,662 & 574 \\
\hline 2298 & 2182 & 1880 & Indonesia University of Education* & 1,516 & 1,081 & 2,356 & 3,111 \\
\hline 2236 & 1834 & 1927 & Universitas Padjadjaran & 1,411 & 3,037 & 2,522 & 2,066 \\
\hline 3302 & 4024 & 2167 & Universitas Mercu Buana & 2,882 & 3,244 & 2,569 & 1,847 \\
\hline 3157 & 2495 & 2335 & Electronic Engineering Polytechnic Institute of Surabaya & 2,336 & 2,465 & 1,622 & 3,842 \\
\hline 2692 & 2609 & 2398 & Universitas Lampung & 2,229 & 4,309 & 1,652 & 3,408 \\
\hline 3620 & 2611 & 2427 & Bina Nusantara University & 3,206 & 2,507 & 1,858 & 3,243 \\
\hline 4878 & 3242 & 2587 & Universitas Muhammadiyah Yogyakarta & 2,939 & 1,313 & 2,22 & 4,382 \\
\hline 3223 & 3092 & 2615 & Universitas Hasanuddin University & 1,626 & 3,414 & 2,156 & 4,382 \\
\hline 3724 & 2754 & 2702 & Universitas Negeri Semarang & 1,591 & 4,414 & 4,323 & 2,646 \\
\hline 2026 & 2085 & 2757 & Brawijaya University * & 2,321 & 4,688 & 3,669 & 2,646 \\
\hline 3481 & 2798 & 2835 & Universitas Udayana & 2,837 & 4,757 & 2,711 & 3,179 \\
\hline
\end{tabular}

(Sumber: http://wWw.webometrics.info/rank_by_country.asp?country=id, diakses tanggal 12/05/11, jam 10:55)

Sedangkan menurut versi QS World University Rankings yang menyediakan informasi/panduan yang objektif mengenai apa yang mungkin perguruan tinggi layak dipertimbangkan untuk mahasiswa. QS, melakukan apa yang diperlukan untuk mendorong evaluasi tersebut ke tingkat yang lebih kontekstual-berfokus pada daerah, mata pelajaran dan sebuah sistem online interaktif di mana enquirers akan mampu memilih kriteria mereka sendiri dan menerapkan pembobotan mereka sendiri-tujuannya adalah untuk mengevaluasi universitas lebih banyak dari sudut yang lebih bagi lebih banyak orang.

Tabel 3

The QS World University Rankings-Top Universities

\begin{tabular}{|c|c|l|c|c|c|c|c|}
\hline $\begin{array}{c}\text { Rank } \\
2009\end{array}$ & $\begin{array}{c}\text { Rank } \\
2010\end{array}$ & \multicolumn{1}{|c|}{ School Name } & Country & Size & Research & Focus & $\begin{array}{c}\text { Score } \\
2010\end{array}$ \\
\hline 2 & 1 & University of Cambridge & United Kingdom & $\mathrm{L}$ & $\mathrm{VH}$ & $\mathrm{FC}$ & 100.00 \\
\hline 1 & 2 & Harvard University & United States & $\mathrm{L}$ & $\mathrm{VH}$ & $\mathrm{FC}$ & 99.18 \\
\hline 3 & 3 & Yale University & United States & $\mathrm{M}$ & $\mathrm{VH}$ & $\mathrm{FC}$ & 98.68 \\
\hline 4 & 4 & UCL (University College London) & United Kingdom & $\mathrm{L}$ & $\mathrm{VH}$ & $\mathrm{FC}$ & 98.54 \\
\hline 9 & 5 & Massachusetts Institute of Technology & United States & $\mathrm{M}$ & $\mathrm{VH}$ & $\mathrm{CO}$ & 98.19 \\
\hline
\end{tabular}




\begin{tabular}{|c|c|l|c|c|c|c|c|}
\hline $\begin{array}{c}\text { Rank } \\
2009\end{array}$ & $\begin{array}{c}\text { Rank } \\
2010\end{array}$ & \multicolumn{1}{|c|}{ School Name } & Country & Size & Research & Focus & $\begin{array}{c}\text { Score } \\
2010\end{array}$ \\
\hline $5=$ & 6 & University of Oxford & United Kingdom & $\mathrm{L}$ & $\mathrm{VH}$ & $\mathrm{FC}$ & 98.16 \\
\hline $5=$ & 7 & Imperial College London & United Kingdom & $\mathrm{L}$ & $\mathrm{VH}$ & $\mathrm{FC}$ & 97.78 \\
\hline 7 & 8 & University of Chicago & United States & $\mathrm{M}$ & $\mathrm{VH}$ & $\mathrm{FC}$ & 97.52 \\
\hline 10 & 9 & California Institute of Technology (Caltech) & United States & $\mathrm{S}$ & $\mathrm{VH}$ & $\mathrm{CO}$ & 96.46 \\
\hline 8 & 10 & Princeton University & United States & $\mathrm{M}$ & $\mathrm{VH}$ & $\mathrm{CO}$ & 96.03 \\
\hline
\end{tabular}

(Sumber: QS Quacquarelli Symonds, wWw.topuniversities.com, diakses tanggal 15/04/2011, jam 13:59)

Tabel 4

Peringkat Dunia Universitas-Universitas di Indonesia Versi The QS World University Rankings

\begin{tabular}{|c|c|c|c|c|c|c|}
\hline $\begin{array}{l}2005 \\
\text { Rank }\end{array}$ & $\begin{array}{l}2006 \\
\text { Rank }\end{array}$ & $\begin{array}{l}2007 \\
\text { Rank }\end{array}$ & $\begin{array}{l}2008 \\
\text { Rank }\end{array}$ & $\begin{array}{l}2009 \\
\text { Rank }\end{array}$ & $\begin{array}{l}2010 \\
\text { Rank }\end{array}$ & School Name \\
\hline & & & & & N/A & Ahmad Dahlan University \\
\hline \multirow[t]{4}{*}{$526=$} & $526=$ & $502=$ & $501+$ & $401-500$ & $451-500$ & Airlangga University \\
\hline & & & & & N/A & Andalas University \\
\hline & & & & & N/A & Atma Jaya Catholic University Jakarta \\
\hline & & & & & N/A & Atma Jaya Yogyakarta University \\
\hline \multirow[t]{3}{*}{$258=$} & $258=$ & $369=$ & 315 & $351=$ & $401-450$ & Bandung Institute of Technology (ITB) \\
\hline & & & & & N/A & Bandung State Polytechnic \\
\hline & & & & & N/A & Bina Nusantara University (BINUS) \\
\hline \multirow[t]{2}{*}{$0=$} & $0=$ & $545=$ & $501+$ & $501-600$ & $501-550$ & Bogor Agricultural University \\
\hline & & & & & N/A & Bunda Mulia University \\
\hline \multirow[t]{32}{*}{$495=$} & $495=$ & 553 & $501+$ & $501-600$ & $601+$ & Diponegoro University \\
\hline & & & & & N/A & Gorontalo State University (GSU) \\
\hline & & & & & N/A & Gunadarma University \\
\hline & & & & & N/A & Hasanuddin University \\
\hline & & & & & N/A & Indonesia Institute of the Arts Surakarta \\
\hline & & & & & N/A & Indonesia Institute of the Arts Yogyakarta \\
\hline & & & & & N/A & Indonesian Institute of Arts Denpasar \\
\hline & & & & & N/A & Islamic University of Indonesia \\
\hline & & & & & N/A & Jember University \\
\hline & & & & & N/A & Maranatha Christian University \\
\hline & & & & & N/A & Merdeka University Malang \\
\hline & & & & & N/A & Muhammadiyah University of Surakarta \\
\hline & & & & & N/A & Padang State University \\
\hline & & & & & N/A & Padjadjaran University \\
\hline & & & & & N/A & Palangka Raya University \\
\hline & & & & & N/A & Pancasila University \\
\hline & & & & & N/A & Parahyangan Catholic University \\
\hline & & & & & N/A & Pasundan University \\
\hline & & & & & N/A & Pelita Harapan University \\
\hline & & & & & N/A & Sanata Dharma University \\
\hline & & & & & N/A & Satya Wacana Christian University \\
\hline & & & & & N/A & Sebelas Maret University \\
\hline & & & & $601+$ & $601+$ & Sepuluh Nopember Institute of Technology \\
\hline & & & & & $\mathrm{N} / \mathrm{A}$ & Soegijapranata Catholic University \\
\hline & & & & & N/A & Sriwijaya University \\
\hline & & & & & N/A & State University of Malang \\
\hline & & & & & N/A & State University of Medan \\
\hline & & & & & N/A & State University of Surabaya \\
\hline & & & & & N/A & Syiah Kuala University \\
\hline & & & & & N/A & Tadulako University \\
\hline & & & & & N/A & Telkom School of Engineering \\
\hline & & & & & N/A & Udayana University \\
\hline \multirow[t]{5}{*}{$270=$} & $270=$ & $360=$ & $316=$ & 250 & 321 & Universitas Gadjah Mada \\
\hline & & & & & N/A & Universitas Pendidikan Indonesia \\
\hline & & & & & N/A & University of 17 Agustus 1945 \\
\hline & & & & & N/A & University of Bengkulu \\
\hline & & N/A & $501+$ & $501-600$ & $601+$ & University of Brawijaya \\
\hline $250=$ & $250=$ & 395 & 287 & $201=$ & 236 & University of Indonesia \\
\hline
\end{tabular}




\begin{tabular}{|c|c|c|c|c|c|c|}
\hline $\begin{array}{l}2005 \\
\text { Rank }\end{array}$ & $\begin{array}{l}2006 \\
\text { Rank }\end{array}$ & $\begin{array}{l}2007 \\
\text { Rank }\end{array}$ & $\begin{array}{l}2008 \\
\text { Rank }\end{array}$ & $\begin{array}{l}2009 \\
\text { Rank }\end{array}$ & $\begin{array}{l}2010 \\
\text { Rank }\end{array}$ & School Name \\
\hline & & & & & N/A & University of Lampung \\
\hline & & & & & N/A & University of Mataram \\
\hline & & & & & N/A & University of Muhammadiyah Malang \\
\hline & & & & & $\mathrm{N} / \mathrm{A}$ & Widya Mandala Catholic University Surabaya \\
\hline & & & & & N/A & Widyagama University of Malang \\
\hline & & & & & N/A & Yogyakarta State University \\
\hline
\end{tabular}

(Sumber: QS World University Rankings ${ }^{\text {TM }}$ Copyright (C 2011 QS Intelligence Unit.

Berdasarkan Tabel 4 tidak terlihat perguruan tinggi di Indonesia tidak termasuk 50 universitas terbaik dunia baik versi Webometrics maupun QS World University Rankings. Hal ini menunjukan bahwa masih lemahnya daya saing perguruan tinggi di Indonesia dibandingkan dengan perguruan tinggi di luar negeri yang pada akhirnya daya saing perguruan tinggi ini akan membangun citra perguruan tingginya.
Citra adalah sejumlah keyakinan, ide dan kesan yang dipegang oleh seseorang terhadap suatu objek (Kotler, 2009:406).

Citra universitas dapat didefinisikan sebagai jumlah dari semua keyakinan yang dimiliki individu terhadap universitas (Landrum et al (1998) dan Arpan et al (2003) dalam Helena Alves and Mário Raposo, 2010:73-85).

Untuk menjadi bagian dari globalisasi dan/atau masyarakat dunia maka perguruan tinggi di Indonesia harus berusaha menjadi perguruan tinggi yang berkelas dunia.

\section{Tabel 5}

\section{QS World University Rankings 2010/2011 Tables and Methodology}

\begin{tabular}{|c|c|c|}
\hline Subject & Academic Criteria & Methodology \\
\hline $\begin{array}{ll}\text { 1. } & \text { Arts \& Humanities } \\
\text { 2. } & \text { Engineering \& Technology } \\
\text { 3. } & \text { Social Sciences \& Management } \\
\text { 4. } & \text { Natural Sciences } \\
\text { 5. } & \text { Life Sciences \& Medicine }\end{array}$ & $\begin{array}{ll}\text { 1. } & \text { Academic Peer Review } \\
\text { 2. } & \text { Employer Review } \\
\text { 3. } & \text { Citations per Faculty } \\
\text { 4. } & \text { Student Faculty } \\
\text { 5. } & \text { International Faculty } \\
\text { 6. } & \text { International Students }\end{array}$ & $\begin{array}{ll}\text { 1. } & \text { Institution inclusion } \\
\text { 2. } & \text { International Faculty (Index) } \\
\text { 3. } & \text { Academic reputation (index) } \\
\text { 4. } & \text { Employer reputation (index) } \\
\text { 5. } & \text { Data indicators } \\
\text { 6. } & \text { Standardization } \\
\text { 7. } & \text { QS classifications } \\
\text { 8. } & \text { QS SAFE }\end{array}$ \\
\hline
\end{tabular}

(Sumber: http://www.topuniversities.com/university-rankings/world-university-rankings, diakses tanggal 17/04/2011, jam 11:53)

Salah satu kriteria penilaian universitas berkelas dunia adalah adanya mahasiswa asing (international student) yang sekolah di universitas tersebut, karena citra international atau berkelas dunia adalah komponen yang harus dimiliki dari universitas kelas dunia saat ini. Salah satu cara untuk mengevaluasi itu adalah menilai proporsi siswa internasional dan fakultas yang paling diminati pada institusi tersebut.

Adanya, mahasiswa asing tersebut merupakan salah satu langkah untuk menjadikan perguruan tinggi di Indonesia kelas dunia. Mahasiswa asing merupakan tanda bahwa perguruan tinggi kita sudah diakui oleh internasional.

Di negeri maju, menjaring mahasiswa asing bukan semata hanya untuk meningkatkan citra perguruan tinggi yang dimaksud seperti di Amerika, pendidikan sudah menjadi ladang bisnis yang amat menggiurkan. Negara adikuasa ini, setiap tahunnya berhasil memperoleh devisa hingga US\$ 13 miliar, hanya dari "menjual" kampus. Begitu juga di Singapura, jumlah mahasiswa dan pelajar asing yang belajar di negara itu, saat ini mencapai sekitar 80 ribu orang, bisa dikatakan, sudah menjadi indikator kemajuan ekonominya. Ada yang memperkirakan, hanya dari sektor pendidikan saja, setiap tahunnya Pemerintah Singapura mendapatkan pemasukan sekitar empat triliun rupiah. Sehingga tidak mengherankan jika Singapura begitu aktif berpromosi ke mancanegara melalui lembaga Singapore Education Service Centre (SESC).

Dengan demikian, citra perusahaan memiliki arti yang sangat penting bagi perusahaan. Citra dapat dipengaruhi oleh perilaku, kepuasan, loyalitas, kreativitas 
dan merek perusahaan secara keseluruhan dan merupakan aset yang sangat berharga.

Menurut Andreassen (1994) dalam penelitiannya mengenai orientasi konsumen mengemukakan bahwa citra adalah sebuah faktor yang penting yang saling berhubungan dengan kepuasan konsumen dan loyalitas. Pengalaman langsung mempunyai pengaruh yang kuat terhadap citra (Selnes, 1993). Konsumen yang memperoleh pengalaman yang memenuhi harapannya dan merasa puas atas pelayanan yang diterimanya akan memiliki sikap positif terhadap sebuah produk. Sikap konsumen ini akan menunjukkan proses pembelian di masa yang akan datang yaitu dengan melakukan konsumsi ulang atau menceritakan kepada orang lain. Sedangkan Ivy (2001) dan Fram (1982) berpendapat bahwa untuk meningkatkan citra dan positioning universitas perlu menekankan pentingnya staf pengajar, orientasi kecenderungan siswa, survei kepuasan mahasiswa dan studi tentang opini publik di masyarakat sekitar universitas, sebagai penentu dalam optimasi citra universitas (Asuncion Beerli Palacio, Gonzalo Diaz Meneses and Pedro J Perez, 2002:486-505).

Kepuasan menjadi salah satu faktor yang mempengaruhi karena kepuasan merupakan ungkapan perasaan pelanggan setelah melakukan perbandingan antara penampilan kinerja produk atau jasa yang didapat dengan yang diharapkan pelanggan atas produk atau jasa tersebut.

Kepuasan dan ketidakpuasan konsumen merupakan dampak dari perbandingan antara harapan konsumen sebelum pembelian dengan yang sesungguhnya diperoleh konsumen dari produk/jasa yang dibeli tersebut.

Kepuasan adalah perasaan seseorang tentang rasa senang atau kecewa karena membandingkan antara kinerja anggapan produk atau hasil dalam hubungannya dengan ekspektasinya (Kotler, 2009:410)

Sedangkan menurut Ham dan Hayduk (2003) dalam Buchari Alma (2008:98), untuk mencapai daya saing perguruan tinggi terdapat tiga faktor yang menjadi global issues dan berpengaruh kepada semua organisasi baik besar maupun kecil, organisasi profit dan non-profit, maupun perusahaan lokal dan global, termasuk didalamnya perguruan tinggi. Ketiga faktor tersebut adalah service quality, customer satisfaction dan behavioral intentions. Hal yang sama diungkapkan oleh peneliti lain yang menyatakan bahwa di pasar yang memiliki persaingan tinggi, kepuasan dengan jasa akan memiliki perbedaan. Kepuasan dimungkinkan dapat berpengaruh terhadap apa yang dirasakan mahasiswa untuk menerima atau menolak.

Oleh karena itu, untuk membentuk citra baik terhadap lembaga, dalam rangka menarik minat sejumlah calon mahasiswa lokal maupun internasional, maka perguruan tinggi selain memperhatikan kepuasan mahasiswa juga harus terus meningkatkan kualitas layanannya.

Menurut Bowen \& Booms (1983) dalam Fandy Tjptono (2008:85), kualitas layanan adalah ukuran seberapa bagus tingkat layanan yang diberikan mampu sesuai dengan ekspekstasi pelanggan.

Apabila jasa yang diterima atau dirasakan sesuai dengan yang diharapkan, maka kualitas jasa dipersepsikan baik dan memuaskan. Jika jasa yang diterima lebih rendah daripada yang diharapkan, maka kualitas jasa dipersepsikan buruk. Sebaliknya jika jasa yang diterima melampaui harapan konsumen, maka kualitas jasa dipersepsikan sebagai kualitas yang ideal. Dengan demikian baik tidaknya kualitas jasa tergantung pada kemampuan penyedia jasa dalam memenuhi harapan konsumennya secara konsisten.

Di kalangan perguruan tinggi dunia, pemeringkatan tersebut (merupakan hasil penilaian 3.000 pakar pendidikan dari seluruh dunia) dipandang cukup bergengsi. Lebih dari itu, pemeringkatan ini bisa dijadikan ukuran menilai kualitas pendidikan yang diselenggarakan perguruan tinggi.

Pemeringkatan tersebut dapat dijadikan media bagi perguruan tinggi yang dimaksud untuk lebih banyak lagi menarik minat mahasiswa asing. Peluangnya ke arah sana memang masih terbuka. Hal itu terungkap dari hasil survei Institute of Internationale Education (lembaga riset dari Amerika) pada tahun 2009. Dari 2,5 juta responden, dari kalangan mahasiswa di seluruh dunia yang disurvei, tidak sedikit di antara mereka (tidak terkecuali mahasiswa berasal dari negara maju) yang mulai berminat menimba ilmu di sejumlah perguruan tinggi negara berkembang. Diantaranya, sekitar 6\% berminat memilih kuliah di Cina. Angka ini mengalahkan peminat yang ingin belajar di Jepang (hanya 5\%) dan Kanada (3\%). Sementara, 
kebanyakan dari mereka (22\%), memang masih memilih Amerika sebagai tujuan utama untuk meraih gelar kesarjanaan.

Bandung menjadi salah satu tujuan mahasiswa asing untuk melanjutkan sekolah karena beragam alasan misalnya cuaca, makanan, teman, keluarga, hingga jaminan kualitas perguruan tinggi di Bandung serta biaya pendidikan pendidikan murah. Kepala imigrasi Bandung Rahmat Tanjung mengungkapkan mahasiswa asing di Bandung mengalami peningkatan sekitar 10\% setiap tahun. Mereka berasal dari Timor Leste, Korea, Malaysia, dan Eropa. Mahasiswa asing dari Eropa dan Amerika memilih Indonesia untuk mempelajari kekayaan budayanya. Pada tahun 2007 saja telah terdaftar sekitar 1000 mahasiswa asing yang kuliah di Bandung. Sedangkan mahasiswa yang telah lulus sebanyak 200 orang. Keberadaan mahasiswa asing memberikan keuntungan tersendiri bagi masyarakat dan pemerintah seperti pendapatan, pertukaran budaya, pengetahuan dan sebagainya. (Sumber : Koran Media Indonesia, 11 Sep 2007)

Institut Teknologi Bandung, Universitas Padjajaran dan Universitas Pendidikan Indonesia yang terletak di Kota Bandung merupakan perguruan tinggi negeri yang dimiliki Indonesia yang telah terpilih menjadi salah satu pilihan mahasiswa asing untuk melanjutkan sekolahnya ke jenjang yang lebih tinggi.

Berbagai upaya dilakukan ITB guna menarik mahasiswa asing lebih banyak lagi agar berminat kuliah di perguruan ini. Diantaranya, secara terus menerus memperbaiki kurikulum pendidikan. ITB menjalin kerja sama dengan puluhan universitas, baik di Kawasan Asia maupun Eropa. Strategi ini juga merupakan bentuk promosi ITB agar lebih dikenal di berbagai negara. Semua langkah itu perlu dilakukan, mengingat "daya jual" ITB dibandingkan dengan sejumlah perguruan tinggi lainnya di Indonesia tergolong lemah. Terutama di kalangan perguruan tinggi yang memiliki fakultas kedokteran, pertanian, atau perikanan. Fakultas Kedokteran misalnya, yang dipandang memiliki daya pikat tersendiri karena berpeluang bisa dikembangkan lewat berbagai kajian mengenai pengobatan penyakit khas yang sering ditemui di daerah tropis. Atau daya tarik di bidang pertanian dan perikanan.

Di mata dunia, Indonesia terkenal oleh ragam kekayaan sumber daya alamnya yang eksklusif. Semua itu tentunya menarik untuk dipelajari. Berbeda dengan ITB, sebagai perguruan tinggi yang mengkaji masalah teknologi, sudah tentu akan kalah bersaing dengan perguruan tinggi terkenal lainnya, terutama yang berada di negara maju, karena belajar soal mesin, di mana saja sama.

\section{Tabel 6}

\section{Beberapa Layanan Untuk Mahasiswa Asing}

di ITB, UNPAD, dan UPI

\begin{tabular}{|c|c|c|}
\hline ITB & UNPAD & UPI \\
\hline $\begin{array}{ll}\text { 1. } & \text { Pengaturan visa } \\
\text { 2. } & \text { Accommodation Arrangement } \\
\text { 3. } & \text { Police Report, } \\
\text { 4. } & \text { Membuka rekening bank } \\
\text { 5. } & \text { Asuransi kesehatan } \\
\text { 6. } & \text { Program pertukaran pelajar dan staf } \\
\text { 7. } & \text { Beasiswa yang ditawarkan oleh universitas- } \\
& \text { universitas asing dan lembaga pendanaan } \\
& \text { lainnya }\end{array}$ & $\begin{array}{l}\text { 1. Konsultasi program pendidikan dan non } \\
\text { akademis yang dipromosikan. } \\
\text { 2. Pendaftaran dan penerimaan siswa baik } \\
\text { konvensional maupun sistem online. } \\
\text { 3. Membantu kedatangan siswa (pick up } \\
\text { service) } \\
\text { 4. Menyediakan asrama siswa Bale } \\
\text { Padjadjaran } \\
\text { 5. Membantu dokumen imigrasi siswa. } \\
\text { 6. Jasa pelayanan kesehatan oleh Klinik } \\
\text { 7. } \quad \text { Padjadjaran. } \\
\text { 8. Tour perjalanan dan wisata oleh Padma } \\
\text { 8. Internet dan layanan } \mathrm{TI} .\end{array}$ & $\begin{array}{ll}\text { 1. } & \text { Pembuatan paspor hijau } \\
\text { 2. } & \text { Pembuatan paspor dinas (biru) } \\
\text { 3. } & \text { Bantuan aplikasi dan permohonan visa } \\
\text { 4. } & \text { Bantuan aplikasi dan calling visa } \\
\text { 5. } & \text { Pembuatan SP setneg } \\
\text { 6. } & \text { Kerjasama UPI dengan universitas dan } \\
\text { 7. lembaga di luar negeri } \\
\text { 7. Pelaksanaan pertukaran dosen, } \\
\text { 8. } \\
\text { 8ahasiswa dan staf } \\
\text { dosen, mahasiswa dan staf ke luar negeri }\end{array}$ \\
\hline
\end{tabular}

(Sumber: ITB, UNPAD, UPI)

ITB melalui International Relation Office (IRO) membantu para siswa internasional dan cendekiawan, untuk mempersiapkan kunjungan mereka ke ITB, termasuk pengaturan visa dan informasi lain untuk membuat tinggal di Bandung nyaman dan menyenangkan, seperti Accommodation Arrangement, Police Report, membuka 
rekening bank, asuransi kesehatan dan sebagainya. IRO ITB juga menyediakan informasi untuk mahasiswa ITB, fakultas dan staf tentang program pertukaran pelajar dan staf, serta beasiswa yang ditawarkan oleh universitasuniversitas asing dan lembaga pendanaan lainnya.

UNPAD melalui PADMA mendukung dan melaksanakan pendidikan internasional yang memenuhi standar universitas kelas dunia, mengatur kegiatan promosi dan kegiatan pemasaran untuk merekrut mahasiswa dari negara-negara target (pameran pendidikan, presentasi, seminar, informasi, iklan, kunjungan ke sekolah di negaranegara target maupun di Indonesia dan lain-lain). PADMA bekerjasama dengan Kedutaan Besar Republik Indonesia di Malaysia menyelenggarakan pameran pendidikan untuk memajukan lembaga-lembaga pendidikan Indonesia yang sudah memiliki program internasional. Konsultasi program pendidikan dan non akademis yang dipromosikan. Pendaftaran dan penerimaan siswa baik konvensional maupun sistem online. Membantu siswa dengan banyak fasilitas dan layanan pendukung mulai dari kedatangan siswa (pick up service), melayani siswa dengan akomodasi yang lengkap dan nyaman untuk mahasiswa asing, PADMA menyediakan asrama siswa Bale Padjadjaran yang dilengkapi dengan fasilitas pendukung seperti: mini mart, koneksi internet, lounge, kantin, fasilitas olahraga dan kebugaran, dan fasilitas hiburan. Membantu dokumen imigrasi siswa. Jasa pelayanan kesehatan oleh Klinik Padjadjaran. Jasa perjalanan dan wisata oleh Padma Tour and Travel serta Internet dan layanan TI.

UPI melalui Office International Education and Relations (OIER) membantu proses penerimaan siswa internasional, menyediakan program penasehat dan dukungan bagi siswa internasional, asrama mahasiswa, beasiswa, pusat kegiatan mahasiswa dan sebagainya.

\section{Kerangka Pemikiran}

Setiap perusahaan melakukan kegiatan pemasaran agar perusahaannya dapat tetap berperan di pasar dan sekaligus dapat menguasai pasar. Kegiatan pemasaran yang dilaksanakan oleh perusahaan tersebut adalah untuk mendekati para pelanggannya, melalui pemberian pemenuhan kebutuhan dan keinginan pelanggan secara memuaskan.

Menurut Hermawan Kartajaya (2002:11), pemasaran merupakan sebuah disiplin bisnis strategis yang mengarahkan proses penciptaan, penawaran dan perubahan values dari satu inisiator kepada stakeholders nya. Landasan filosofis yang mendasari definisi tersebut dapat dijabarkan dalam bentuk visi, misi dan nilai dari pemasaran itu sendiri. (1) Visi - bahwa pemasaran harus menjadi suatu konsep bisnis strategis yang dapat memberi kepuasan berkelanjutan, bukan kepuasan sesaat untuk tiga stakeholder utama yaitu pelanggan, karyawan dan pemilik. Di dalam lembaga pendidikan kepuasan harus diutaman bagi tiga komponen yaitu siswa, guru/dosen/karyaean dan pemilik (pemerintah/yayasan). (2) Misi - bahwa pemasaran akan menjadi jiwa, bukan sekedar salah satu anggota atau bagian saja dalam lembaga yang harus aktif dalam pemasaran, tapi semua lini harus menjadi pemasar ulung, semua harus merasa terpanggil menjapai tujuan lembaga yaitu memberi kepuasan. (3) Nilai - menjaga merek agar lebih melekat dihati pelanggan, setiap orang dalam lembaga harus merasa terlibat dalam proses pemuasan pelanggan. Karyawan bukan hanya sebagai petugas saja perpanjangan tangan dari atasan tapi semua karyawan harus mampu menambah nilai terhadap kepuasan pelanggan.

Oleh karena itu peranan stratejik pemasaran sangat penting. Menurut Craven dalam Buchari Alma (2007:257) bahwa:

Strategic marketing is a market driven process of strategy development, taking into account a constantly changing business environment and the need to achieve high levels of customer satisfaction. strategic marketing focuses on organizational performance rather than the traditional concern about increasing sales.

Stratejik pemasaran sangat mengutamakan orientasi pada pelanggan dengan memberikan kepuasan tertinggi dan fokus pada tampilan lembaga dalam melayani pelanggan dan ini berbeda dengan pemasaran tradisional yang hanya mengutamakan peningkatan volume penjualan. Dengan perencanaan yang dilakukan secara aktif dan baik akan dapat mengantisipasi perkembangan masa depan, bahkan faktor diluar lingkungan bisnis akan dapat dikuasai atau diramalkan lebih dulu.

Menurut Hermawan Kertajaya (2002:72), ada tiga dimensi pemasaran yang diringkas dengan simbol STV yaitu: (1) Strategi yang memenangkan mind share. Strategi 
berusaha untuk menanamkan nama lembaga beserta produknya dibenak pelanggan, ini bertujuan untuk mencapai how to win the market. (2) Tactic untuk memenangkan market share. Taktik pemasaran seperti menggunakan berbagai teknik promosi, pengabdian kepada masyarakat adalah dalam rangka mengusahakan penguasaan pasar, dengan istilah lain how to penetrate a market. (3) Value untuk memenangkan heart share. Value bertujuan untuk merebut tempat dihati pelanggan atau how to create an emotions touch. Value merupakan tujuan para produsen karena telah terjadi pergeseran selera pelanggan dimana fitur dan benefit tidak cukup lagi untuk memuaskan pelanggan. Pelanggan tidak lagi sebagai makhluk yang rasional tapi juga emosional, yang membuat para customer service menjadi sangat penting. Sekarang sangat penting kualita layanan sebagai alat persaingan yang ampuh untuk mempertahankan langganan, membangun standar kualitas yang excellence.

Pada pemasaran jasa, pendekatan strategis diarahkan pada kemampuan pemasar menemukan cara untuk "mewujudkan" yang tidak berwujud, meningkatkan produktivitas penyedia yang tidak terpisahkan dari produk itu, membuat standar kualitas sehubungan dengan adanya variabilitas, dan mempengaruhi gerakan permintaan dan pemasok kapasitas mengingat jasa tidak tahan lama.

Menurut Zeithaml dalam Buchari Alma (2007:250) jasa dikelompokan ke dalam berbagai jenis, yaitu: (1) Transportasi termasuk didalamnya kereta api, bus, truk, transportasi air, udara dan sebagainya, (2) Komunikasi berupa telepon, radio, dan televisi, (3) Public utilities berupa listrik, gas, dan kebersihan, (4) Perdagangan besar termasuk agen-agen dari produsen, (5) Perdagangan eceran termasuk didalamnya berbagai bentuk pertokoan, (6) Keuangan, asuransi, dan perumahan berupa simpan pinjam, bursa efek, perusahaan investasi, usaha pembangunan perumahan (7) Jasa hotel, (8) Personal services, (9) Business services, (10) Jasa parkir, (11) Jasa bengkel/reparasi, (12) Jasa bioskop hiburan dan rekreasi, (13) Jasa di bidang kesehatan, (14) Jasa dibidang hukum, (15) Jasa pendidikan, (16) Jasa sosial atau masyarakat, (17) Jasa organisasi, (19) Jasa yang ditawarkan oleh pemerintah, perizinan, keamanan polisi/TNI dan sebagainya.

Ada dua variabel besar dalam strategi pemasaran yaitu (1) variabel yang tidak dapat dikontrol seperti keadaan persaingan, perkembangan teknologi, perubahan demografik, kebijakan politik dan ekonomis, sumber daya alam. (2) variabel yang dapat dikontrol seperti segmentasi pasar, biaya pemasaran, timing, dan bauran pemasaran (Alex D Triyana MBA dalam Buchari Alma, 2007:201).

Bauran pemasaran merupakan strategi mencampur kegiatan-kegiatan pemasaran, agar dicari kombinasi maksimal sehingga mendatangkan hasil paling memuaskan. Menurut Buchari Alma dan Ratih Hurriyati (2008:154), bauran pemasaran jasa pendidikan adalah elemen-elemen organisasi pendidikan yang dapat dikontrol oleh organisasi dalam melakukan komunikasi dengan peserta didik dan akan dipakai untuk memuaskan peserta didik.

Bauran pemasaran jasa terdiri atas tujuh elemen yaitu: product, promotion, place, price, physical evidence, people, and process. Dalam menetapkan bauran pemasaran untuk mencapai target, maka kita harus menetapkan bauran pemasaran yang sebaik-baiknya yaitu bahwa bauran pemasaran harus seimbang, tidak boleh statis, tidak boleh meniru, harus bertujuan jangka panjang, dan harus berdasarkan pengalaman.

Oleh karena itu, dalam persaingan yang semakin meningkat dan agar bauran pemasaran dapat dilaksanakan dengan baik guna mencapai tujuan atau target, maka perusahaan jasa harus menjaga kualitas layanan yang ditawarkannya harus berada di atas saingan dan lebih hebat dari yang dibayangkan oleh pelanggan. Apabila kualitas layanan yang diterima oleh pelanggan lebih baik atau sama dengan yang dibayangkan maka pelanggan cenderung akan mencobanya kembali. Akan tetapi bila kualitas layanan yang diterimanya lebih rendah dari yang dibayangkan maka pelanggan akan kecewa dan akan berhenti berhubungan dengan perusahaan jasa yang bersangkutan.

Secara sederhana kualitas layanan merupakan ukuran seberapa bagus tingkat layanan yang diberikan mampu sesuai dengan ekspektasi pelanggan (Lewis \& Booms, 1983, dalam Fandi Tjiptono, 2008:85). Dari definisi ini, kualitas layanan bisa diwujudkan melalui pemenuhan kebutuhan dan keinginan pelanggan serta ketepatan penyampaiannya untuk mengimbangi harapan pelanggan.

Kualitas dalam pendidikan tinggi mungkin lebih sulit untuk didefinisikan daripada di sektor-sektor yang lain. 
Frazer (1994) berpendapat bahwa langkah penting pertama agar istilah disetujui secara internasional antara lain level/tingkat, standard, efektivitas, dan efisiensi. Martens dan Prosser (1998) menekankan pentingnya kualitas pembelajaran, yang harus difokuskan pada makna dan bukan pada reproduksi. Ramsden (1992) menggarisbawahi bahwa kompetensi vital dalam disiplin akademis dalam memahami cara di mana siswa menangkap dan memahami fenomena yang berkaitan dengan subjek.

Membahas kualitas pendidikan tinggi, Harvey dan Green (1993) mengusulkan lima cara terpisah tetapi saling terkait pemikiran tentang kualitas yaitu: (1) Quality As Exceptional (kualitas sebagai hal yang luar biasa), (2) Quality As Perfection Or Consistency (kualitas sebagai kesempurnaan atau konsistensi), (3) Quality As Fitness For Purpose (kualitas sebagai kesesuaian untuk tujuan), (4) Quality As Value For Money (kualitas sebagai nilai untuk uang), (5) Quality As Transformation (kualitas sebagai transformasi).

Sedangkan Green (1994) berpendapat bahwa mengingat kesulitan dalam mendefinisikan kualitas dalam pendidikan tinggi maka perlu untuk mendefinisikan sejelas mungkin kriteria yang digunakan masing-masing stakeholder ketika menilai kualitas.

Para peneliti kemudian mengembangkan berbagai kriteria dan/atau dimensi dalam kualitas layanan. Himpunan dimensi yang paling terkenal diusulkan oleh Parasuraman et al. (1985) dan Zeithaml et al. (1990). Dimensi yang awalnya disertakan antara lain: (1) Reliability (2) Responsiveness, (3) Competence, (4) Access, (5) Courtesy, (6) Communication, (7) Credibility, (8) Security, (9) Understanding the customer, (10) Tangibles.

Dalam kerangka alternatif, Grönroos (2000) menyajikan kompilasi dari tujuh kriteria kualitas pelayanan yang dianggap baik. Dia menyatakan bahwa kriteria ini merupakan integrasi studi yang tersedia dan kerja konseptual, antara lain: (1) Professionalism and skill, (2) Attitude and behaviour, (3) Accessibility and flexibility, (4) Reliability and trustworthiness, (5) Service recovery, (6) Serviscape, (7) Reputation and credibility.

Pada kualitas layanan jasa pendidikan tinggi, Garvin (1987) mengusulkan delapan dimensi yang dapat menjelaskan baik kualitas produk dan layanannya, yaitu: (1) performance (kinerja), (2) features (fitur), (3) reliability (keandalan), (4) comformance (kesesuaian), (5) durability (daya tahan), (6) serviceability (kemampuan layanan), (7) aesthetics (estetika), (8) perceived quality (persepsi kualitas).

McElwee dan Redman (1993) menggunakan model dimensi kualitas pelayanan (SERVQUAL) yang dikembangkan oleh Parasuraman et al. (1985, 1988) sebagai dasar untuk model yang disesuaikan untuk pendidikan tinggi. Struktur rangka SERVQUAL, penekanan utamanya ditempatkan pada fungsional (interaktif) aspek kualitas. Hill (1995) juga meneliti implikasi dari teori mutu pelayanan pendidikan tinggi. Dalam studi lain, Anderson (1995) menggunakan SERVQUAL untuk menilai kualitas dari sebuah bagian administrasi di sebuah universitas (kantor pelayanan mahasiswa).

Dalam penelitian ini kualitas layanan yang digunakan berdasarkan enam dimensi kualitas layanan jasa pendidikan dari Mohammad S. Owlia and Elaine M. Aspinwall (1996:12-20) yang disesuaikan dengan standar yang dikeluarkan oleh QS Star, dimana sistem QS star dalam mengevaluasi universitas atas berbagai indikator kinerja penting berdasarkan metode peringkat. Tujuan dari penilaian QS star adalah untuk menilai perguruan tinggi sesuai dengan kriteria yang lebih luas, memberikan mereka kesempatan yang lebih besar untuk keunggulan di bidang khusus mereka. QS star juga menawarkan suatu standar internasional untuk perbandingan setiap institusi yang berpartisipasi. Hal ini sangat berguna untuk universitas dalam upaya meningkatkan pemasaran internasional mereka. Penghargaan dilisensikan untuk sebuah institusi untuk menonjolkan rating star institusi di semua komunikasi visual. QS star ini menyorot keunggulan institusi secara keseluruhan, atau dapat juga digunakan untuk menyoroti kekuatan spesialisnya, yaitu:

1. Tangibles, dengan indikator Asrama mahasiswa, Fasilitas kegiatan proses belajar mengajar (ruang kuliah, laboratorium dan sebagainya), Fasilitas perpustakaan, Infrastruktur TI, Fasilitas pendukung keagamaan bagi mahasiswa internasional, Fasilitas medis, Kegiatan/organisasi mahasiswa, Fasilitas olahraga, Akomodasi mahasiswa

2. Competence, dengan indikator Rasio perbandingan jumlah dosen dengan mahasiswa asing, Rasio kualifikasi dosen S2, S3, Guru Besar atau Profesor, Kemampuan dosen dalam penguasaan bahan ajar 
secara penuh dan metode pengajaran baik pedagogis dan metodis (Kompetensi profesional dosen), Relevansi pengetahuan dan/atau bahan ajar dengan fenomena yang sedang terjadi (up to date), Kemampuan mengajar (Kompetensi pedagogis dosen), Potensipotensi psikologis dosen untuk tugas-tugas kependidikan, seperti kebutuhan untuk berprestasi, bekerja, berubah, dan otonom (Kompetensi kepribadian), dan sebagainya

3. Attitude, dengan indikator Kesopanan dan kerapihan dosen, Menghormati dan menghargai mahasiswa asing secara wajar, Rasa tanggung jawab yang besar demi masa depan mahasiswanya, Bersikap sabar dalam mehadapi mahasiswanya tanpa menggunakan emosi dalam bertindak, Saat mengajar dosen berbicara dan/atau bersuara dengan jelas, Menciptakan suasana kelas yang baik, Kesediaan dosen memberikan bimbingan dan saran pada mahasiswa asing, Kesediaan dosen untuk membantu, bergaul dan melayani mahasiswa asing yang berhubungan dengan pekerjaan dosen, dan sebagainya

4. Content, dengan indikator Relevansi kurikulum dengan kebutuhan dan keinginan mahasiswa, Layanan pembelajaran tatap muka, Layanan pembelajaran tugas terstruktur dan/atau mandiri, Layanan pembelajaran di luar kelas, Pemantapan, try out, program pamong, dan sebagainya, Ketersediaan layanan kedatangan mahasiswa asing (pick up service) dan kepulangan, Ketersediaan pembuatan dokumen mahasiswa asing seperti paspor, visa, asuransi kesehatan, rekening bank, dan police report, Layanan administrasi akademik, kemahasiswaan dan keuangan.

5. Delivery, dengan indikator Ketepatan waktu penyampaian materi perkuliahan, Konsistensi penyampaian materi perkuliahan, Ketepatan dan keadilan mengevaluasi hasil belajar, Ketepatan waktu penyampaian layanan administrasi, Konsistensi penyampaian layanan administrasi.

6. Ketepatan/ketelitian dalam setiap layanan yang diberikan

7. Reliability dengan indikator Kemampuan menjaga kepercayaan, Ketepatan menepati janii agar sesuai dengan tujuan, Kemampuan menangani keluhan dan pemecahan masalah.
Kualitas layanan ini mempengaruhi pelanggan dalam menggunakan sebuah jasa. Untuk memenuhi kepuasan pelanggan pada industri jasa, kualitas pelayanan sangat penting dikelola dengan baik. Dengan kualitas pelayanan yang baik tentunya pelanggan akan merasa puas. Kepuasan pelanggan dapat tercipta dengan adanya kualitas jasa pelayanan yang baik dengan kata lain semakin tinggi tingkat kualitas pelayanan semakin besar kepuasan pelanggan yang dirasakan dan sebaliknya semakin rendah tingkat kualitas pelayanan maka semakin kecil kepuasan pelanggan yang dirasakan.

Kualitas apabila dikelola dengan tepat dapat berkontribusi positif terhadap terwujudnya kepuasan pelanggan. Kualitas memberikan nilai plus berupa motivasi khusus bagi para pelanggan untuk menjalin ikatan relasi saling menguntungkan dalam jangka panjang dengan perusahaan. Ikatan emosional semacam ini memungkinkan perusahaan untuk memahami dengan seksama harapan dan kebutuhan spesifik pelanggan. Pada gilirannya, perusahaan dapat meningkatkan kepuasan pelanggan dimana perusahaan berusaha memaksimumkan pengalaman pelanggan yang menyenangkan dan meminimumkan atau meniadakan pengalaman pelanggan yang kurang menyenangkan. (Fandy Tjiptono, 2008:83).

Dalam institusi pendidikan tinggi, memberikan kualitas pelayanan telah menjadi salah satu tujuan penting yang harus dicapai. Para praktisi sering menganggap bahwa kualitas pelayanan adalah sama dengan kepuasan konsumen.

Kualitas layanan didefinisikan sebagai evaluasi keseluruhan dari kebaikan atau keburukan suatu produk atau jasa. Dengan kata lain, itu adalah sikap. Kepuasan konsumen ini sama dengan sikap, tetapi jangka pendek dan hasil dari evaluasi terhadap pengalaman konsumsi tertentu (Adee Athiyaman, 1997:528-540).

Sedangkan Parasuraman at. al (1991) mengartikan kualitas sebagai suatu bentuk sikap, berhubungan namun tidak sama dengan kepuasan, yang merupakan hasil dari perbandingan antara harapan dengan kinerja aktual. Selanjutnya disebutkan bahwa pengertian yang paling umum dari perbedaan kualitas pelayanan dan kepuasan adalah bahwa kualitas pelayanan merupakan satu bentuk sikap, penilaian dilakukan dalam waktu lama, sementara kepuasan merupakan ukuran dari transaksi yang spesifik 
Kepuasan adalah perasaan seseorang tentang rasa senang atau kecewa karena membandingkan antara kinerja anggapan produk atau hasil dalam hubungannya dengan ekspektasinya (Kotler, 2009:410).

Kepuasan/ketidakpuasan adalah hasil evaluasi dari sebuah transaksi yang spesifik atau pengalaman konsumsi (Adee Athiyaman, 1997:528-540). Kepuasan pelanggan adalah sebuah konsep abstrak dan agak ambigu. Manifestasi kepuasan bervariasi dari satu orang ke orang lain dan dari satu produk ke produk yang lain. Keadaan dari apa yang disebut "kepuasan" tergantung pada sejumlah variabel psikologis dan fisik, dan menghubungkannya dengan perilaku tertentu. Diantara variabel-variabel psikologis, keyakinan pribadi, sikap dan evaluasi dapat mempengaruhi kepuasan pelanggan (Ajzen dan Fishbein, 1980). Dalam konteks ini, sikap terhadap kualitas pendidikan tinggi diyakini mempengaruhi kepuasan individu. Menurut Oliver (1981), kepuasan pelanggan adalah relatif sementara dan konsumsi-spesifik, sedangkan sikap relatif bertahan. Westbrook dan Oliver (1981) berpendapat bahwa kepuasan adalah evaluasi dari totalitas situasi pembelian relatif terhadap harapan, sedangkan sikap adalah keinginan untuk suatu produk atau jasa yang tidak memiliki unsur perbandingan. Oleh karena itu, dari perspektif ini bahwa tingkat kepuasan dapat bervariasi, tergantung pada alternatif yang tersedia untuk pelanggan.

Kepuasan mahasiswa didefinisikan sebagai ringkasan evaluatif pengalaman pendidikan langsung, didasarkan pada kesenjangan antara harapan sebelumnya dan kinerja yang dirasakan setelah melewati siklus pendidikan. Karena kepuasan adalah keadaan psikologis, upaya mengukur dalamnya adalah seringkali sarat dengan peringatan. (Corneliu Munteanu, Ciprian Ceobanu, Claudia Bobålca and Oana Anton, 2010:124-140)

Banyak lembaga pendidikan tinggi melakukan beberapa evaluasi kualitas pendidikan yang diberikan kepada siswa, serta penilaian kepuasan siswa. Kepuasan mahasiswa merupakan indikator yang semakin penting dari kualitas kinerja pengajaran dan juga dapat dianggap sebagai ukuran hasil dari proses pendidikan (Ramsden, 1991). Mengukur kepuasan siswa bukanlah tugas yang mudah untuk dicoba. Oleh karena itu, indikator yang digunakan berbeda dari satu peneliti dengan peneliti lainnya. Sebagai contoh, Browne et al (1998) menemukan bahwa kepuasan global dalam sebuah universitas didorong oleh penilaian siswa tentunya kualitas dan faktor kurikulum terkait lainnya yang berhubungan dengan universitas. Borden (1995) menemukan bahwa kepuasan siswa berkaitan dengan perbandingan antara prioritas mahasiswa dan lingkungan kampus (Elliott dan Shin, 2002).

Menurut Corneliu Munteanu, Ciprian Ceobanu, Claudia Bobålca and Oana Anton (2010:124-140), kualitas yang dirasakan dari kegiatan dalam lembaga pendidikan tinggi dapat digambarkan juga dalam hal kepuasan dengan seperangkat karakteristik universitas umum.

Kepuasan siswa yang dikembangkan oleh NoelLevitz menilai tingkat kepentingan dan kepuasan yang dirasakan dengan 11 dimensi sebagai berikut: (1) Academic advising effectiveness, (2) Campus climate/klim kampus, (3) Campus life/kehidupan kampus, (4) Campus support services/ayanan pendukung kampus, (5) Concern for the individualkepedulian individu, (6) Instructional effectiveness/efektifitas instruksional, (7) Recruitment and financial aid effectiveness/perekrutan dan efektivitas bantuan keuangan, (8) Registration effectiveness/efektivitas pendaftaran, (9) Campus safety and security/keselamatan dan keamanan kampus, (10) Service excellence/pelayanan prima, (11) Student centeredness/pusat kesiswaan (Elliott dan Shin, 2002).

Helgesen dan Nesset (2007) menunjukkan bahwa kepuasan siswa memiliki dampak positif terhadap persepsi siswa atas citra universitas.

Yavas dan Shemwell (1996), Landrum et al. (1998) dan Parameswaran dan Glowacka (1995) menemukan bahwa lembaga-lembaga pendidikan tinggi perlu untuk mempertahankan atau mengembangkan citra yang berbeda untuk menciptakan keunggulan kompetitif dalam pasar yang semakin kompetitif. Citra merupakan salah satu pengaruh utama pada kesediaan siswa untuk mengajukan permohonan pendaftaran. Citra universitas juga penting ketika para donatur mempertimbangkan hibah atau perusahaan memilih sebuah lembaga yang dikontrak untuk melakukan penelitian dan pengembangan. Menurut Dowling (1988) perusahaan tidak hanya memiliki satu citra, namun beberapa citra. Namun, literatur tentang citra universitas seperti yang dirasakan oleh mahasiswa dan bagaimana citra ini mempengaruhi perilaku mereka tetap langka. (Helena Alves and Mário Raposo, 2010:73-85). 
Citra adalah seperangkat keyakinan, ide dan kesan yang dimiliki oleh seseorang terhadap suatu objek, sikap dan tindakan orang terhadap sangat ditentukan oleh citra obyek tersebut (Kotler, 2009:406). Citra universitas dapat didefinisikan sebagai jumlah dari semua keyakinan yang dimiliki individu terhadap universitas (Landrum et al (1998) dan Arpan et al (2003)

Oleh karena itu, citra perguruan tinggi merupakan salah satu faktor dalam meningkatkan daya saing yang merupakan salah satu elemen kunci intangible resources yang akan menjadi sumber dari penciptaan kondisi keunggulan daya saing berkelanjutan (sustainable competitive advantage) suatu perusahaan. Citra tersebut diperoleh melalui serangkaian kemampuan dan pengalaman yang terakumulasi sehingga perguruan tinggi tersebut memiliki kinerja terbaik bagi stakeholder.

Citra terhadap perguruan tinggi, terbentuk berdasarkan banyak unsur yang berkumpul dalam bentuk komponen. Komponen-komponen ini antara lain:

"Academic reputation, campus appearance, cost, personal attention, location, distance from home, graduate and professional school preparation, career placement, social activities, program of study and size" (Huddleston, 1982:365 dalam Buchari Alma, 2007:377)

Menurut Volkwein dan Grunig dalam dalam Buchari Alma dan Ratih Hurriyati (2008:116) bahwa untuk mengkur citra perguruan tinggi meliputi financial resources, faculty credentials, student test scores, external funding, dan rating and rankings.

Keaveney dan Hunt (1992) berpendapat bahwa dalam rangka menjaring secara keseluruhan kekayaan citra perusahaan komersial, komponen kognitif dan afektif harus disertakan, karena mereka memberikan pemahaman dan pengukuran citra. Selain itu, Stern dan Krakover (1993) menekankan bahwa citra keseluruhan terbentuk subjektif melalui sistem yang terkait erat dengan persepsi designative dan evaluatif, dengan kata lain, komponen kognitif dan afektif.

Dalam penelitian ini, komponen pembentuk citra perguruan tinggi yang digunakan adalah berdasarkan komponen yang dikemukakan oleh Asuncion Beerli Palacio, Gonzalo dan Meneses Diaz Pedro J. Perez (2002:486-505) yaitu:
1. Komponen kognitif, dengan indikator Paper/makalah penelitian dosen banyak dipublikasikan secara internasional. Dosen banyak yang berasal dari luar negeri yang mengajar di universitas, Proses belajar mengajar yang ditawarkan sangat baik, Universitas telah dikenal secara internasional dengan baik, Memiliki ranking atau peringkat keunggulan dalam bidang khusus, Universitas memiliki layanan pendukung bimbingan karir yang baik, Universitas memiliki sumber daya yang baik bagi siswa (seperti peralatan komputer, perpustakaan, transportasi, dan lain-lain), dan sebagainya.

2. Komponen afektif, dengan indikator Keinginan untuk mengikuti program-program seperti double degree, fullbright, sandwich, dan lain-lain di universitas, Penilaian terhadap universitas ini di tingkat internasional, Apresiasi anda terhadap universitas ini, Kemampuan anda berinteraksi dengan lingkungan sosial dan budaya di universitas ini.

Kualitas apabila dikelola dengan tepat dapat berkontribusi positif terhadap terwujudnya kepuasan pelanggan. Kualitas memberikan nilai plus berupa motivasi khusus bagi para pelanggan untuk menjalin ikatan relasi saling menguntungkan dalam jangka panjang dengan perusahaan. Ikatan emosional semacam ini memungkinkan perusahaan untuk memahami dengan seksama harapan dan kebutuhan spesifik pelanggan. Pada gilirannya, perusahaan dapat meningkatkan kepuasan pelanggan dimana perusahaan berusaha memaksimumkan pengalaman pelanggan yang menyenangkan dan meminimumkan atau meniadakan pengalaman pelanggan yang kurang menyenangkan. (Fandy Tjiptono, 2008:83). Quality is clearly the key to value creation and customer satisfaction (Kotler and Kevin Lane Keller, 2009:170)

Kepuasan pelanggan akan mempengaruhi citra suatu perusahaan atau organisasi, hal ini sesuai dengan pernyataan yang dikemukakan oleh Andreassen (1994) dalam penelitiannya mengenai orientasi konsumen mengemukakan bahwa citra adalah sebuah faktor yang penting yang saling berhubungan dengan kepuasan konsumen dan loyalitas. Pengalaman langsung mempunyai pengaruh yang kuat terhadap citra (Selnes, 1993). Konsumen yang memperoleh pengalaman yang memenuhi harapannya dan merasa puas atas pelayanan yang 
diterimanya akan memiliki sikap positif terhadap sebuah produk. Sikap konsumen ini akan menunjukkan proses pembelian di masa yang akan datang yaitu dengan melakukan konsumsi ulang atau menceritakan kepada orang lain. Oleh Manickas et. al. (1997) dan Ryan (1999) dinyatakan bahwa seluruh bentuk keputusan akan memberikan pengaruh positif terhadap citra. Kepuasan dan loyalitas pelanggan juga dipengaruhi oleh citra (Yi, 1992).

Menurut Oliver dan Linda (1981), Bolton dan Drew (1991) dan Foraell (1992) menunjukkan bahwa citra memiliki pengaruh yang kuat pada kepuasan pelanggan. Helgesen dan Nesset (2007) menunjukkan bahwa kepuasan siswa memiliki dampak positif terhadap persepsi siswa dari citra universitas. Andreassen dan Lindestad
(1998) memverifikasi bahwa citra perusahaan mempengaruhi kepuasan pelanggan terutama jika pelanggan memiliki sedikit pengetahuan tentang layanan (Helena Alves and Mário Raposo, 2010:73-85)

Ivy (2001) dan Fram (1982) berpendapat bahwa untuk meningkatkan citra dan positioning serta menekankan pentingnya staf pengajar, orientasi kecenderungan siswa, survei kepuasan mahasiswa dan studi tentang opini publik di masyarakat sekitar universitas, sebagai penentu dalam optimasi citra universitas (Asuncion Beerli Palacio, Gonzalo Diaz Meneses and Pedro J Perez, 2002:486-505).

Berdasarkan uraian di atas maka dapat digambarkan kerangka pemikiran sebagai berikut:

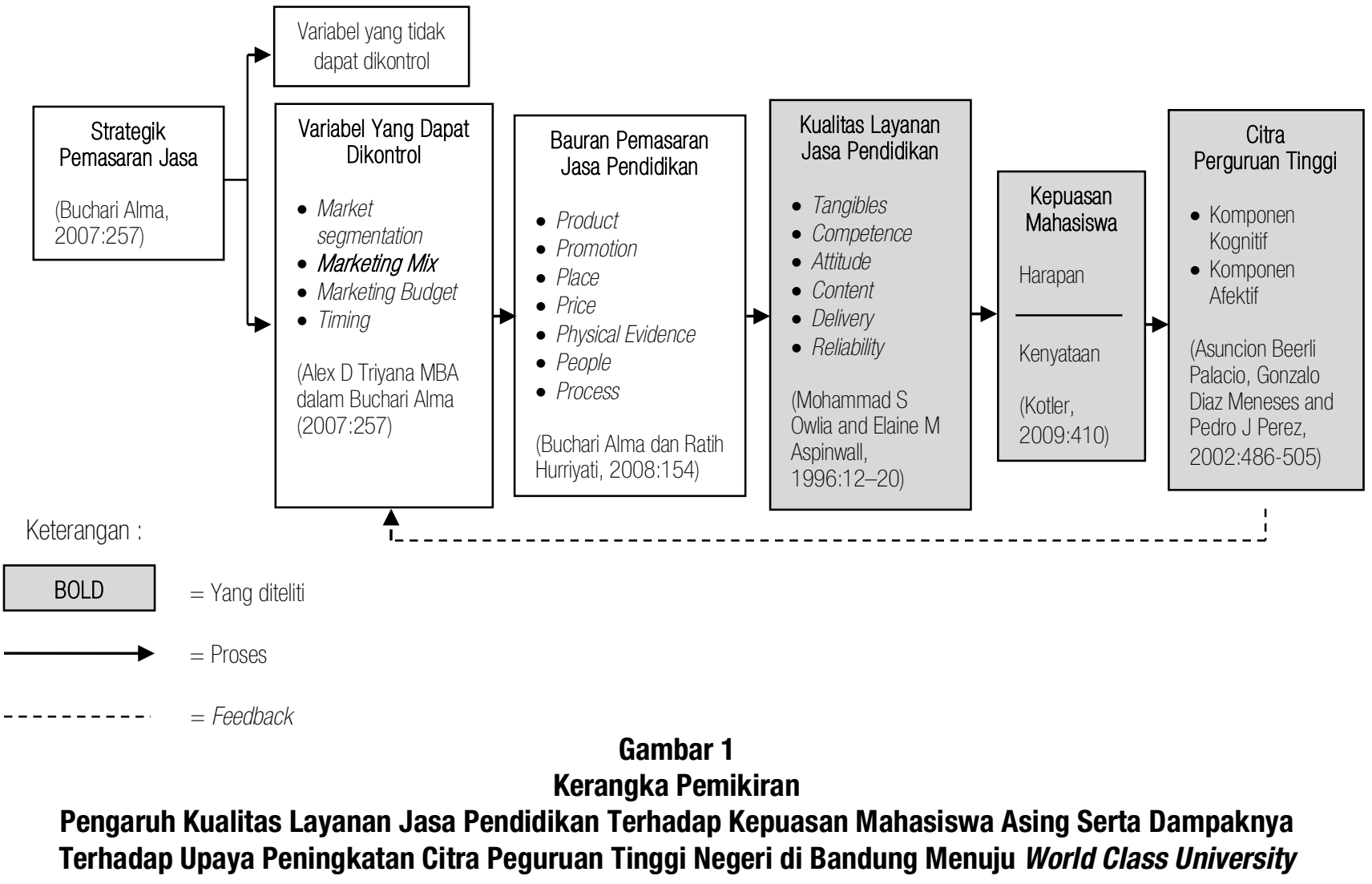

\subsection{Hipotesis Penelitian}

Hipotesis dapat diartikan sebagai suatu jawaban yang bersifat sementara terhadap permasalahan penelitian sampai terbukti melalui data yang terkumpul (Sugiyono, 2003:38).

Hipotesis yang diajukan penulis sebagai berikut:

"Terdapat pengaruh antara kualitas layanan jasa pendidikan terhadap kepuasan mahasiswa asing serta dampaknya terhadap upaya peningkatan citra perguruan tinggi negeri di Bandung menuju world class university baik secara simultan maupun parsial". 


\section{Metode Penelitian}

Berdasarkan tujuan penelitian, penelitian ini bersifat penelitian deskriptif dan verifikatif. Dalam penelitian ini akan di uji apakah kualitas layanan jasa pendidikan memiliki pengaruh terhadap kepuasan mahasiswa asing serta dampaknya terhadap citra perguruan tinggi negeri di Bandung. maka metode penelitian yang digunakan adalah survey explanatory.

Adapun penelitian ini dilakukan dalam jangka waktu kurang dari satu tahun sehingga metode yang digunakan adalah cross-sectional yaitu metode penelitian dengan cara mempelajari objek dalam satu kurun waktu tertentu (tidak berkesinambungan dalam jangka panjang). (Husain Umar, 2001:45).

Populasi sasaran dalam penelitian ini adalah mahasiswa asing perguruan tinggi negeri di Bandung yaitu Institut Teknologi Bandung, Universitas Padjajaran dan Universitas Pendidikan Indonesia. Tabel 7 berikut ini merupakan rincian jumlah populasinya:

\section{Tabel 7}

\section{Populasi Mahasiswa Asing Pada Perguruan Tinggi Negeri di Bandung}

\begin{tabular}{|c|c|}
\hline Perguruan Tinggi Negeri di Bandung & Jumlah \\
\hline Institut Teknologi Bandung & 169 \\
\hline Universitas Padjajaran & 990 \\
\hline Universitas Pendidikan Indonesia & 45 \\
\hline Jumlah & 1204 \\
\hline
\end{tabular}

(Sumber: ITB, UNPAD, UPI)

Dalam menentukan ukuran sampel dalam penelitian ini digunakan rumus sampel Slovin (Husein Umar, 2003;141) yaitu sebagai berikut :

$$
\mathrm{n}=\frac{N}{1+N e^{2}}
$$

Dimana :

$\mathrm{n}=$ sampel

$\mathrm{N}=$ populasi

$\mathrm{e}=$ taraf kesalahan

Berdasarkan perhitungan di atas, dengan ukuran sampel minimal yang digunakan dalam penelitian ini dengan $\boldsymbol{\alpha}=0,1$ dan derajat kepercayaan 10\%, maka diperoleh ukuran sampel (n) minimal 92 orang. Agar sampel yang digunakan lebih representatif dalam penelitian ini, maka sampel yang digunakan adalah 100 orang responden. Perhitungan proporsional sampelnya dapat dilihat pada tabel berikut ini:

Tabel 8

Perhitungan Proporsional Sampel

\begin{tabular}{|c|c|c|c|}
\hline $\begin{array}{c}\text { Perguruan Tinggi } \\
\text { Negeri Di Bandung }\end{array}$ & $\begin{array}{c}\text { Jumlah } \\
\text { Populasi }\end{array}$ & Proporsional & Sampel \\
\hline ITB & 169 & $\frac{169}{1204} \times 100$ & 14 \\
\hline UNPAD & 990 & $\frac{990}{1204} \times 100$ & 82 \\
\hline UPI & 45 & $\frac{45}{1204} \times 100$ & 4 \\
\hline
\end{tabular}

(Sumber: Hasil Pengolahan Data)

Perhitungan proporsional sampel di atas memperoleh hasil sampel masing-masing untuk Institut Teknologi Bandung sebanyak 14 orang responden, untuk Universitas Padjajaran sebanyak 84 orang responden dan untuk Universitas Pendidikan Indonesia sebanyak 4 orang responden.

Teknik sampling yang digunakan pada penelitian ini adalah simple random sampling. Untuk menguji validitas menggunakan product moment atau pearson (Pearson's Product Moment Coeffisient of Correlation), yaitu:

$$
r=\frac{n\left(\sum X Y\right)-\left(\sum X\right)\left(\sum Y\right)}{\sqrt{\left\{\left[n\left(\sum X^{2}\right)-\left(\sum X\right)^{2}\right]\left[n\left(\sum Y^{2}\right)-\left(\sum Y\right)^{2}\right]\right\}}}
$$

Keterangan:

$r \quad=$ Koefisien validitas item yang dicari

$x \quad=$ Skor yang diperoleh subjek seluruh item

$Y \quad=$ Skor total

$\sum X=$ Jumlah skor dalam distribusi $X$

$\sum Y=$ Jumlah skor dalam distribusi $Y$

$\sum X^{2}=$ Jumlah kuadrat dalam skor distribusi $X$

$\sum Y^{2}=$ Jumlah kuadrat dalam skor distribusi $Y$

$\mathrm{N} \quad=$ Banyaknya responden

Teknik analisis data yang digunakan dalam penelitian ini menggunakan Structural Equation Modelling (SEM). 


\section{Tabel 9}

Tanggapan Mahasiswa Asing Terhadap Kualitas Layanan ITB, UNPAD, UPI

\begin{tabular}{|l|c|c|c|c|c|}
\hline \multicolumn{1}{|c|}{ Item } & ITB & UNPAD & UPI & $\begin{array}{c}\text { Rata- } \\
\text { Rata }\end{array}$ & Kategori \\
\hline Tangible & 3,5 & 3,9 & 3,6 & 3,7 & Baik \\
\hline Competence & 3,7 & 3,9 & 4,4 & 4,0 & Baik \\
\hline Attitude & 3,8 & 3,9 & 4,3 & 4,0 & Baik \\
\hline Content & 3,7 & 3,8 & 4,5 & 4,0 & Baik \\
\hline Delivery & 3,8 & 3,8 & 4,3 & 4,0 & Baik \\
\hline Reliability & 3,8 & 3,9 & 4,5 & 4,1 & Sangat Baik \\
\hline Rata-Rata & 3,7 & 3,9 & $\mathbf{4 , 3}$ & 4,0 & Baik \\
\hline
\end{tabular}

Secara keseluruhan gambaran kualitas layanan jasa pendidikan di perguruan tinggi negeri di Bandung dilakukan melalui penjelasan enam dimensi yaitu tangibles, competence, attitude, content, content, delivery, dan reliability.

Tabel 10

Rekapitulasi Kualitas Layanan Jasa Pendidikan

\begin{tabular}{|c|c|c|c|c|c|c|c|c|}
\hline \multirow{2}{*}{ No } & \multirow{2}{*}{\multicolumn{2}{|c|}{ Ukuran }} & \multicolumn{4}{|c|}{ Perolehan Skor } & \multirow{3}{*}{$\begin{array}{l}\text { Skor } \\
\text { Ideal } \\
500\end{array}$} & \multirow{3}{*}{$\begin{array}{l}\% \\
76\end{array}$} \\
\hline & & & \multirow{2}{*}{$\begin{array}{c}\text { ITB } \\
49 \\
\end{array}$} & \multirow{2}{*}{$\begin{array}{c}\text { UNPAD } \\
316 \\
\end{array}$} & \multirow{2}{*}{$\begin{array}{c}\text { UPI } \\
15 \\
\end{array}$} & \multirow{2}{*}{$\begin{array}{c}\text { Jumlah } \\
380 \\
\end{array}$} & & \\
\hline 1 & \multirow{9}{*}{ 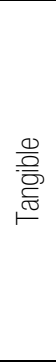 } & Asrama mahasiswa & & & & & & \\
\hline 2 & & $\begin{array}{l}\text { Fasilitas kegiatan proses belajar mengajar (ruang kuliah, laboratorium dan } \\
\text { sebagainya) }\end{array}$ & 60 & 348 & 17 & 425 & 500 & 85 \\
\hline 3 & & Fasilitas perpustakaan & 60 & 338 & 17 & 415 & 500 & 83 \\
\hline 4 & & Infrastruktur TI & 45 & 293 & 16 & 354 & 500 & 70,8 \\
\hline 5 & & Fasilitas pendukung keagamaan bagi mahasiswa internasional & 43 & 292 & 13 & 348 & 500 & 69,6 \\
\hline 6 & & Fasilitas medis & 49 & 315 & 12 & 376 & 500 & 75,2 \\
\hline 7 & & Kegiatan/organisasi mahasiswa & 52 & 327 & 12 & 391 & 500 & 78,2 \\
\hline 8 & & Fasilitas olahraga & 47 & 314 & 16 & 377 & 500 & 75,4 \\
\hline \multirow[t]{2}{*}{9} & & Akomodasi mahasiswa & 41 & 304 & 10 & 355 & 500 & 71 \\
\hline & & Total & & & & 3421 & 4500 & 76 \\
\hline 10 & \multirow{9}{*}{ 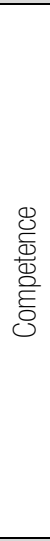 } & Rasio perbandingan jumlah dosen dengan mahasiswa asing & 48 & 306 & 18 & 372 & 500 & 74,4 \\
\hline 11 & & Rasio kualifikasi dosen S2, S3, Guru Besar atau Profesor & 49 & 306 & 17 & 372 & 500 & 74,4 \\
\hline 12 & & $\begin{array}{l}\text { Kemampuan dosen dalam penguasaan bahan ajar secara penuh dan metode } \\
\text { pengajaran baik pedagogis dan metodis (Kompetensi profesional dosen). }\end{array}$ & 55 & 335 & 17 & 407 & 500 & 81,4 \\
\hline 13 & & $\begin{array}{l}\text { Relevansi pengetahuan dan/atau bahan ajar dengan fenomena yang sedang } \\
\text { terjadi (up to date). }\end{array}$ & 56 & 338 & 19 & 413 & 500 & 82,6 \\
\hline 14 & & Kemampuan mengajar (Kompetensi pedagogis dosen). & 53 & 319 & 19 & 391 & 500 & 78,2 \\
\hline 15 & & $\begin{array}{l}\text { Potensi-potensi psikologis dosen untuk tugas-tugas kependidikan, seperti } \\
\text { kebutuhan untuk berprestasi, bekerja, berubah, dan otonom (Kompetensi } \\
\text { kepribadian). }\end{array}$ & 53 & 313 & 16 & 382 & 500 & 76,4 \\
\hline 16 & & Rasio perbandingan jumlah staf administrasi dengan mahasiswa asing & 53 & 322 & 17 & 392 & 500 & 78,4 \\
\hline 17 & & $\begin{array}{l}\text { Kemampuan staf bekerja dalam tim, pelayanan prima, berkomunikasi efektif, dan } \\
\text { membangun hubungan kerja }\end{array}$ & 48 & 310 & 17 & 375 & 500 & 75 \\
\hline \multirow[t]{2}{*}{18} & & $\begin{array}{l}\text { Potensi-potensi staf seperti etos kerja, fleksibilitas, ketelitian, kedisiplinan, kreatif } \\
\text { dan inovasi, integritas dan tanggung jawab }\end{array}$ & 50 & 315 & 17 & 382 & 500 & 76,4 \\
\hline & & Total & & & & 3486 & 4500 & 77,5 \\
\hline 19 & \multirow{11}{*}{ 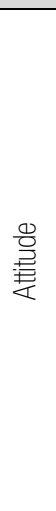 } & Kesopanan dan kerapihan dosen & 57 & 338 & 20 & 415 & 500 & 83 \\
\hline 20 & & Menghormati dan menghargai mahasiswa asing secara wajar & 52 & 313 & 19 & 384 & 500 & 76,8 \\
\hline 21 & & Rasa tanggung jawab yang besar demi masa depan mahasiswanya & 56 & 316 & 17 & 389 & 500 & 77,8 \\
\hline 22 & & $\begin{array}{l}\text { Bersikap sabar dalam mehadapi mahasiswanya tanpa menggunakan emosi dalam } \\
\text { bertindak. }\end{array}$ & 56 & 322 & 19 & 397 & 500 & 79,4 \\
\hline 23 & & Saat mengajar dosen berbicara dan/atau bersuara dengan jelas & 53 & 317 & 17 & 387 & 500 & 77,4 \\
\hline 24 & & Menciptakan suasana kelas yang baik & 54 & 322 & 18 & 394 & 500 & 78,8 \\
\hline 25 & & Kesediaan dosen memberikan bimbingan dan saran pada mahasiswa asing & 57 & 318 & 18 & 393 & 500 & 78,6 \\
\hline 26 & & $\begin{array}{l}\text { Kesediaan dosen untuk membantu, bergaul dan melayani mahasiswa asing yang } \\
\text { berhubungan dengan pekerjaan dosen. }\end{array}$ & 56 & 327 & 16 & 399 & 500 & 79,8 \\
\hline 27 & & $\begin{array}{l}\text { Kemampuan menyenangkan mahasiswa asing melalui kesopansantunan yang } \\
\text { baik dan kerapihan. }\end{array}$ & 55 & 311 & 16 & 382 & 500 & 76,4 \\
\hline 28 & & Menghormati dan menghargai mahasiswa asing secara wajar. & 58 & 330 & 18 & 406 & 500 & 81,2 \\
\hline 29 & & Rasa tanggung jawab yang besar dan memberikan keyakinan pada mahasiswa & 55 & 313 & 15 & 383 & 500 & 76,6 \\
\hline
\end{tabular}




\begin{tabular}{|c|c|c|c|c|c|c|c|c|}
\hline \multirow{2}{*}{ No } & \multirow{2}{*}{\multicolumn{2}{|c|}{ Ukuran }} & \multicolumn{4}{|c|}{ Perolehan Skor } & \multirow{2}{*}{$\begin{array}{l}\text { Skor } \\
\text { Ideal }\end{array}$} & \multirow{2}{*}{$\%$} \\
\hline & & & ITB & UNPAD & UPI & Jumlah & & \\
\hline \multirow[b]{2}{*}{30} & & asing atas jasa atau layanan universitas. & & & & & & \\
\hline & & $\begin{array}{l}\text { Berkomunikasi dengan bijaksana dalan melakukan sesuatu dengan benar pada } \\
\text { saat yang tepat. }\end{array}$ & 53 & 317 & 16 & 386 & 500 & 77,2 \\
\hline \multirow{3}{*}{$\frac{31}{32}$} & & Kemampuan staf memahami kebutuhan mahasiswa asing. & 45 & 285 & 15 & 345 & 500 & 69 \\
\hline & & Kesediaan staf memberikan bimbingan dan saran pada mahasiswa asing. & 48 & 304 & 17 & 369 & 500 & 73,8 \\
\hline & & $\begin{array}{l}\text { Kesediaan staf untuk membantu, bergaul dan melayani mahasiswa asing yang } \\
\text { berhubungan dengan pekerjaan staf. }\end{array}$ & 51 & 325 & 16 & 392 & 500 & 78,4 \\
\hline & & Total & & & & 5821 & 7500 & 77,6 \\
\hline 34 & \multirow{8}{*}{ 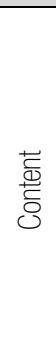 } & Relevansi kurikulum dengan kebutuhan dan keinginan mahasiswa & 54 & 325 & 20 & 399 & 500 & 79,8 \\
\hline 35 & & Layanan pembelajaran tatap muka & 50 & 318 & 19 & 387 & 500 & 77,4 \\
\hline 36 & & Layanan pembelajaran tugas terstruktur dan/atau mandiri & 51 & 319 & 20 & 390 & 500 & 78 \\
\hline 37 & & Layanan pembelajaran di luar kelas & 48 & 297 & 16 & 361 & 500 & 72,2 \\
\hline \multirow{2}{*}{$\begin{array}{ll}38 \\
39\end{array}$} & & Pemantapan, try out, program pamong, dan sebagainya & 49 & 308 & 16 & 373 & 500 & 74,6 \\
\hline & & $\begin{array}{l}\text { Ketersediaan layanan kedatangan mahasiswa asing (pick up service) dan } \\
\text { kepulangan }\end{array}$ & 54 & 316 & 18 & 388 & 500 & 77,6 \\
\hline 40 & & $\begin{array}{l}\text { Ketersediaan pembuatan dokumen mahasiswa asing seperti paspor, visa, } \\
\text { asuransi kesehatan, rekening bank, dan police report. }\end{array}$ & 55 & 313 & 17 & 385 & 500 & 77 \\
\hline \multirow[t]{2}{*}{41} & & Layanan administrasi akademik, kemahasiswaan dan keuangan & 51 & 300 & 17 & 368 & 500 & 73,6 \\
\hline & & Total & & & & 3051 & 4000 & 76,3 \\
\hline 42 & \multirow{6}{*}{ 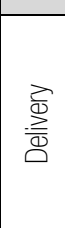 } & Ketepatan waktu penyampaian materi perkuliahan & 52 & 313 & 18 & 383 & 500 & 76,6 \\
\hline 43 & & Konsistensi penyampaian materi perkuliahan. & 53 & 317 & 19 & 389 & 500 & 77,8 \\
\hline 44 & & Ketepatan dan keadilan mengevaluasi hasil belajar & 53 & 329 & 17 & 399 & 500 & 79,8 \\
\hline 45 & & Ketepatan waktu penyampaian layanan administrasi & 51 & 305 & 17 & 373 & 500 & 74,6 \\
\hline 46 & & Konsistensi penyampaian layanan administrasi. & 54 & 315 & 14 & 383 & 500 & 76,6 \\
\hline \multirow[t]{2}{*}{47} & & Ketepatan/ketelitian dalam setiap layanan yang diberikan. & 53 & 312 & 18 & 383 & 500 & 76,6 \\
\hline & & Total & & & & 2310 & 3000 & 77 \\
\hline 48 & \multirow{3}{*}{ 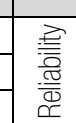 } & Kemampuan menjaga kepercayaan. & 55 & 324 & 18 & 397 & 500 & 79,4 \\
\hline \multirow{4}{*}{$\begin{array}{ll}49 \\
50\end{array}$} & & Ketepatan menepati janij agar sesuai dengan tujuan. & 54 & 314 & 18 & 386 & 500 & 77,2 \\
\hline & & Kemampuan menangani keluhan dan pemecahan masalah & 51 & 317 & 18 & 386 & 500 & 77,2 \\
\hline & & Total & & & & 1169 & 1500 & 77,9 \\
\hline & & Total Skor & & & & 19258 & 25000 & 77 \\
\hline
\end{tabular}

(Sumber: Hasil pengolahan data)

\subsection{Tingkat Kepuasan Mahasiswa Asing Perguruan Tinggi Negeri Di Bandung}

Gambaran kepuasan mahasiswa asing dari kualitas layanan di perguruan tinggi negeri di Bandung dilakukan melalui enam dimensi yaitu tangibles, competence, attitude, content, content, delivery, dan reliability.

Berdasarkan indeks kepuasan pelanggan yang diperoleh melalui metode Importance Performance Analysis dari hasil tanggapan mahasiswa asing di perguruan tinggi negeri di Bandung diperoleh nilai 79,0102\% yang merupakan termasuk kategori puas. Sedangkan indeks kepuasan pelanggan di ITB sebesar 74,6993\%, UNPAD sebesar 78,1503\% dan UPI sebesar 86,6392\%.

\subsection{Tingkat Kepuasan Mahasiswa Asing Perguruan Tinggi Negeri Di Bandung}

Gambaran kepuasan mahasiswa asing dari kualitas layanan di perguruan tinggi negeri di Bandung dilakukan melalui enam dimensi yaitu tangibles, competence, attitude, content, content, delivery, dan reliability.

Berdasarkan indeks kepuasan pelanggan yang diperoleh melalui metode Importance Performance Analysis dari hasil tanggapan mahasiswa asing di perguruan tinggi negeri di Bandung diperoleh nilai 79,0102\% yang merupakan termasuk kategori puas. Sedangkan indeks kepuasan pelanggan di ITB sebesar 74,6993\%, UNPAD sebesar 78,1503\% dan UPI sebesar 86,6392\%. 
Tabel 11

Analisis Importance Performance Analysis (IPA) dan Customer Satisfaction Index (CSI)

\begin{tabular}{|c|c|c|c|c|c|c|c|c|c|c|}
\hline \multirow[b]{2}{*}{ No. } & \multicolumn{5}{|c|}{ Persepsi } & \multicolumn{5}{|c|}{ Ekspektasi } \\
\hline & ITB & UNPAD & UPI & Rata2 & $\begin{array}{l}\text { Bobot } \\
\text { Persepsi }\end{array}$ & ITB & UNPAD & UPI & Rata2 & $\begin{array}{c}\text { Bobot } \\
\text { Ekspektasi }\end{array}$ \\
\hline 1 & 3,5 & 3,9 & 3,8 & 3,7 & 0,0795 & 4,7 & 4,5 & 4,5 & 4,6 & 0,0215 \\
\hline 2 & 4,3 & 4,2 & 4,3 & 4,3 & 0,0922 & 4,3 & 4,5 & 5,0 & 4,6 & 0,0216 \\
\hline 3 & 4,3 & 4,1 & 4,3 & 4,2 & 0,0887 & 4,1 & 4,3 & 5,0 & 4,5 & 0,0210 \\
\hline 4 & 3,2 & 3,6 & 4,0 & 3,6 & 0,0739 & 4,0 & 4,1 & 5,0 & 4,4 & 0,0205 \\
\hline 5 & 3,1 & 3,6 & 3,3 & 3,3 & 0,0625 & 3,5 & 4,3 & 4,3 & 4,0 & 0,0190 \\
\hline 6 & 3,5 & 3,8 & 3,0 & 3,4 & 0,0714 & 3,9 & 4,3 & 5,0 & 4,4 & 0,0207 \\
\hline 7 & 3,7 & 4,0 & 3,0 & 3,6 & 0,0660 & 3,8 & 4,0 & 4,0 & 3,9 & 0,0185 \\
\hline 8 & 3,4 & 3,8 & 4,0 & 3,7 & 0,0667 & 3,6 & 4,0 & 3,8 & 3,8 & 0,0179 \\
\hline 9 & 2,9 & 3,7 & 2,5 & 3,0 & 0,0578 & 3,5 & 4,1 & 4,5 & 4,0 & 0,0190 \\
\hline 10 & 3,5 & 3,7 & 4,3 & 3,8 & 0,0727 & 3,9 & 4,4 & 3,8 & 4,0 & 0,0190 \\
\hline 11 & 3,9 & 4,1 & 4,3 & 4,1 & 0,0791 & 3,9 & 4,4 & 4,0 & 4,1 & 0,0193 \\
\hline 12 & 4,0 & 4,1 & 4,8 & 4,3 & 0,0904 & 4,1 & 4,5 & 4,8 & 4,5 & 0,0210 \\
\hline 13 & 3,8 & 3,9 & 4,8 & 4,2 & 0,0850 & 3,9 & 4,3 & 4,8 & 4,3 & 0,0204 \\
\hline 14 & 3,8 & 3,9 & 4,8 & 4,2 & 0,0876 & 4,1 & 4,3 & 5,0 & 4,5 & 0,0210 \\
\hline 15 & 3,8 & 3,8 & 4,0 & 3,9 & 0,0752 & 4,0 & 4,1 & 4,3 & 4,1 & 0,0194 \\
\hline 16 & 3,8 & 3,9 & 4,3 & 4,0 & 0,0759 & 4,1 & 4,2 & 3,8 & 4,0 & 0,0190 \\
\hline 17 & 3,4 & 3,8 & 4,3 & 3,8 & 0,0770 & 3,8 & 4,2 & 4,8 & 4,3 & 0,0201 \\
\hline 18 & 3,6 & 3,8 & 4,3 & 3,9 & 0,0801 & 3,9 & 4,2 & 5,0 & 4,4 & 0,0205 \\
\hline 19 & 4,1 & 4,1 & 5,0 & 4,4 & 0,0939 & 4,4 & 4,2 & 5,0 & 4,5 & 0,0213 \\
\hline 20 & 3,7 & 3,8 & 4,8 & 4,1 & 0,0836 & 3,9 & 4,3 & 4,8 & 4,3 & 0,0204 \\
\hline 21 & 4,0 & 3,9 & 4,3 & 4,1 & 0,0855 & 4,2 & 4,2 & 5,0 & 4,5 & 0,0210 \\
\hline 22 & 4,0 & 3,9 & 4,8 & 4,2 & 0,0890 & 4,2 & 4,2 & 5,0 & 4,5 & 0,0210 \\
\hline 23 & 3,8 & 3,9 & 4,3 & 4,0 & 0,0822 & 4,0 & 4,1 & 5,0 & 4,4 & 0,0205 \\
\hline 24 & 3,9 & 3,9 & 4,5 & 4,1 & 0,0849 & 3,9 & 4,3 & 5,0 & 4,4 & 0,0207 \\
\hline 25 & 4,1 & 3,9 & 4,5 & 4,2 & 0,0876 & 4,2 & 4,2 & 5,0 & 4,5 & 0,0210 \\
\hline 26 & 4,0 & 4,0 & 4,0 & 4,0 & 0,0828 & 4,0 & 4,4 & 4,8 & 4,4 & 0,0207 \\
\hline 27 & 3,9 & 3,8 & 4,0 & 3,9 & 0,0777 & 4,0 & 4,2 & 4,5 & 4,2 & 0,0199 \\
\hline 28 & 4,1 & 4,0 & 4,5 & 4,2 & 0,0883 & 4,2 & 4,2 & 5,0 & 4,5 & 0,0210 \\
\hline 29 & 3,9 & 3,8 & 3,9 & 3,9 & 0,0776 & 4,1 & 4,2 & 4,5 & 4,3 & 0,0201 \\
\hline 30 & 3,8 & 3,9 & 4,0 & 3,9 & 0,0789 & 3,9 & 4,2 & 4,8 & 4,3 & 0,0202 \\
\hline 31 & 3,2 & 3,5 & 3,8 & 3,5 & 0,0659 & 3,4 & 4,1 & 4,5 & 4,0 & 0,0188 \\
\hline 32 & 3,4 & 3,7 & 4,3 & 3,8 & 0,0763 & 3,6 & 4,2 & 5,0 & 4,3 & 0,0201 \\
\hline 33 & 3,6 & 4,0 & 4,0 & 3,9 & 0,0728 & 3,6 & 4,1 & 4,3 & 4,0 & 0,0188 \\
\hline 34 & 3,9 & 4,0 & 5,0 & 4,3 & 0,0870 & 4,0 & 4,4 & 4,5 & 4,3 & 0,0202 \\
\hline 35 & 3,6 & 3,9 & 4,8 & 4,1 & 0,0817 & 3,8 & 4,4 & 4,5 & 4,2 & 0,0199 \\
\hline 36 & 3,6 & 3,9 & 5,0 & 4,2 & 0,0830 & 4,0 & 4,2 & 4,5 & 4,2 & 0,0199 \\
\hline 37 & 3,4 & 3,6 & 4,0 & 3,7 & 0,0702 & 3,7 & 4,0 & 4,5 & 4,1 & 0,0191 \\
\hline 38 & 3,5 & 3,8 & 4,0 & 3,8 & 0,0691 & 3,6 & 4,1 & 4,0 & 3,9 & 0,0184 \\
\hline 39 & 3,9 & 3,9 & 4,5 & 4,1 & 0,0804 & 3,8 & 4,2 & 4,5 & 4,2 & 0,0196 \\
\hline 40 & 3,9 & 3,8 & 4,3 & 4,0 & 0,0822 & 3,9 & 4,2 & 5,0 & 4,4 & 0,0205 \\
\hline 41 & 3,6 & 3,7 & 4,3 & 3,9 & 0,0788 & 3,8 & 4,2 & 5,0 & 4,3 & 0,0204 \\
\hline 42 & 3,7 & 3,8 & 4,5 & 4,0 & 0,0772 & 3,6 & 4,2 & 4,5 & 4,1 & 0,0193 \\
\hline 43 & 3,8 & 3,9 & 4,8 & 4,2 & 0,0843 & 3,9 & 4,2 & 4,8 & 4,3 & 0,0202 \\
\hline 44 & 3,8 & 4,0 & 4,3 & 4,0 & 0,0822 & 3,9 & 4,3 & 4,8 & 4,3 & 0,0204 \\
\hline 45 & 3,6 & 3,7 & 4,3 & 3,9 & 0,0764 & 3,6 & 4,2 & 4,8 & 4,2 & 0,0198 \\
\hline 46 & 3,9 & 3,8 & 3,5 & 3,7 & 0,0708 & 3,9 & 4,2 & 4,0 & 4,0 & 0,0190 \\
\hline 47 & 3,8 & 3,8 & 4,5 & 4,0 & 0,0803 & 3,7 & 4,2 & 4,8 & 4,2 & 0,0199 \\
\hline 48 & 3,9 & 4,0 & 4,5 & 4,1 & 0,0817 & 4,0 & 4,1 & 4,5 & 4,2 & 0,0198 \\
\hline 49 & 3,9 & 3,8 & 4,5 & 4,1 & 0,0791 & 3,9 & 4,2 & 4,3 & 4,1 & 0,0194 \\
\hline 50 & 3,9 & 3,9 & 4,5 & 4,1 & 0,0778 & 3,6 & 4,2 & 4,3 & 4,0 & 0,0190 \\
\hline Rata2 & & & & 3,9 & & & & & 4,3 & \\
\hline Jumlah & & & & 197,2 & 3,9505 & & & & 212,5 & \\
\hline CSI & & & & & 79,0102 & & & & & \\
\hline
\end{tabular}

Keterangan No.Item:

1. Asrama mahasiswa

2. Fasilitas kegiatan proses belajar mengajar (ruang kuliah, laboratorium dan sebagainya)

26. Kesediaan dosen untuk membantu, bergaul dan melayani mahasiswa asing yang berhubungan dengan pekerjaan dosen.

27. Kemampuan menyenangkan mahasiswa asing melalui kesopansantunan yang baik dan kerapihan.

3. Fasilitas perpustakaan 
4. Infrastruktur TI

5. Fasilitas pendukung keagamaan bagi mahasiswa internasional

6. Fasilitas medis

7. Kegiatan/organisasi mahasiswa

8. Fsilitas olahraga

9. Akomodasi mahasiswa

10. Rasio perbandingan jumlah dosen dengan mahasiswa asing.

11. Rasio kualifikasi dosen S2, S3, Guru Besar atau Profesor.

12. Kemampuan dosen dalam penguasaan bahan ajar secara penuh dan metode pengajaran baik pedagogis dan metodis (Kompetensi profesional dosen).

13. Relevansi pengetahuan dan/atau bahan ajar dengan fenomena yang sedang terjadi (up to date).

14. Kemampuan mengajar (Kompetensi pedagogis dosen).

15. Potensi-potensi psikologis dosen untuk tugas-tugas kependidikan, seperti kebutuhan untuk berprestasi, bekerja, berubah, dan otonom (Kompetensi kepribadian).

16. Rasio perbandingan jumlah staf administrasi dengan mahasiswa asing.

17. Kemampuan staf bekerja dalam tim, pelayanan prima, berkomunikasi efektif, dan membangun hubungan kerja

18. Potensi-potensi staf seperti etos kerja, fleksibilitas, ketelitian, kedisiplinan, kreatif dan inovasi, integritas dan tanggung jawab

19. Kesopanan dan kerapihan dosen.

20. Menghormati dan menghargai mahasiswa asing secara wajar.

21. Rasa tanggung jawab yang besar demi masa depan mahasiswanya.

22. Bersikap sabar dalam mehadapi mahasiswanya tanpa menggunakan emosi dalam bertindak.

23. Saat mengajar dosen berbicara dan/atau bersuara dengan jelas.

24. Menciptakan suasana kelas yang baik.

25. Kesediaan dosen memberikan bimbingan dan saran pada mahasiswa asing

(Sumber: Hasil pengolahan data)
28. Menghormati dan menghargai mahasiswa asing secara wajar.

29. Rasa tanggung jawab yang besar dan memberikan keyakinan pada mahasiswa asing atas jasa atau layanan universitas.

30. Berkomunikasi dengan bijaksana dalan melakukan sesuatu dengan benar pada saat yang tepat.

31. Kemampuan staf memahami kebutuhan mahasiswa asing.

32. Kesediaan staf memberikan bimbingan dan saran pada mahasiswa asing.

33. Kesediaan staf untuk membantu, bergaul dan melayani mahasiswa asing yang berhubungan dengan pekerjaan staf.

34. Relevansi kurikulum dengan kebutuhan dan keinginan mahasiswa.

35. Layanan pembelajaran tatap muka.

36. Layanan pembelajaran tugas terstruktur dan/atau mandiri.

37. Layanan pembelajaran di luar kelas.

38. Pemantapan, try out, program pamong, dan sebagainya.

39. Ketersediaan layanan kedatangan mahasiswa asing (pick up service) dan kepulangan.

40. Ketersediaan pembuatan dokumen mahasiswa asing seperti paspor, visa, asuransi kesehatan, rekening bank, dan police report.

41. Layanan administrasi akademik, kemahasiswaan dan keuangan.

42. Ketepatan waktu penyampaian materi perkuliahan

43. Konsistensi penyampaian materi perkuliahan.

44. Ketepatan dan keadilan mengevaluasi hasil belajar.

45. Ketepatan waktu penyampaian layanan administrasi.

46. Konsistensi penyampaian layanan administrasi.

47. Ketepatan/ketelitian dalam setiap layanan yang diberikan.

48. Kemampuan menjaga kepercayaan.

49. Ketepatan menepati janji agar sesuai dengan tujuan.

50. Kemampuan menangani keluhan dan pemecahan masalah.

Gambaran Citra ITB, UNPAD, UPI

\begin{tabular}{|l|c|c|c|c|}
\hline \multicolumn{1}{|c|}{ Unit } & Kognitif & Afektif & Rata-Rata & Kategori \\
\hline ITB & 3,62 & 3,59 & 3,61 & Positif \\
\hline UNPAD & 4,04 & 3,77 & 3,91 & Positif \\
\hline UPI & 3,73 & 3,88 & 3,81 & Positif \\
\hline Rata-Rata & 3,80 & 3,75 & 3,77 & Positif \\
\hline
\end{tabular}

(Sumber: Hasil pengolahan data)

Secara keseluruhan gambaran citra perguruan tinggi negeri di Bandung dilakukan melalui komponen kognitif dan afektif.

Tabel 13

Rekapitulasi Citra Perguruan Tinggi

\begin{tabular}{|c|c|c|c|c|c|c|c|c|}
\hline \multirow{2}{*}{ No } & \multirow{2}{*}{\multicolumn{2}{|c|}{ Ukuran }} & \multicolumn{4}{|c|}{ Perolehan Skor } & \multirow{2}{*}{$\begin{array}{l}\text { Skor } \\
\text { Ideal }\end{array}$} & \multirow{2}{*}{$\%$} \\
\hline & & & ITB & UNPAD & UPI & Jumlah & & \\
\hline 1 & \multirow{9}{*}{ 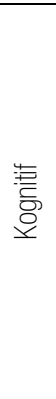 } & Paper/makalah penelitian dosen banyak dipublikasikan secara internasional. & 49 & 328 & 11 & 388 & 500 & 77,60 \\
\hline 2 & & Dosen banyak yang berasal dari luar negeri yang mengajar di universitas. & 37 & 291 & 9 & 337 & 500 & 67,40 \\
\hline 3 & & Proses belajar mengajar yang ditawarkan sangat baik. & 49 & 315 & 18 & 382 & 500 & 76,40 \\
\hline 4 & & Universitas telah dikenal secara internasional dengan baik. & 52 & 342 & 18 & 412 & 500 & 82,40 \\
\hline 5 & & Memiliki ranking atau peringkat keunggulan dalam bidang khusus. & 57 & 353 & 17 & 427 & 500 & 85,40 \\
\hline 6 & & Universitas memiliki layanan pendukung bimbingan karir yang baik. & 51 & 336 & 15 & 402 & 500 & 80,40 \\
\hline 7 & & $\begin{array}{l}\text { Universitas memiliki sumber daya yang baik bagi siswa (seperti peralatan } \\
\text { komputer, perpustakaan, transportasi, dll). }\end{array}$ & 44 & 320 & 16 & 380 & 500 & 76,00 \\
\hline 8 & & $\begin{array}{l}\text { Universitas memiliki program akademik/departemen/sekolah yang dikenal } \\
\text { secara internasional. }\end{array}$ & 55 & 339 & 15 & 409 & 500 & 81,80 \\
\hline 9 & & Banyaknya mahasiswa internasional. & 56 & 340 & 17 & 413 & 500 & 82,60 \\
\hline 10 & & $\begin{array}{l}\text { Mahasiswa banyak yang mengikuti pertukaran mahasiswa dengan } \\
\text { universitas lain dari luar negeri. }\end{array}$ & 52 & 332 & 15 & 399 & 500 & 79,80 \\
\hline 11 & & $\begin{array}{l}\text { Program untuk masuk universitas yang diselenggarakan tidak sulit (seperti } \\
\text { double degree, fullbright, sandwich, dll). }\end{array}$ & 48 & 340 & 13 & 401 & 500 & 80,20 \\
\hline
\end{tabular}




\begin{tabular}{|c|c|c|c|c|c|c|c|c|}
\hline \multirow{2}{*}{ No } & \multirow{2}{*}{\multicolumn{2}{|c|}{ Ukuran }} & \multicolumn{4}{|c|}{ Perolehan Skor } & \multirow{2}{*}{$\begin{array}{l}\text { Skor } \\
\text { Ideal }\end{array}$} & \multirow{2}{*}{$\%$} \\
\hline & & & ITB & UNPAD & UPI & Jumlah & & \\
\hline 12 & & $\begin{array}{l}\text { Universitas berpengalaman dalam menyelenggarakan program-program } \\
\text { internasional. }\end{array}$ & 58 & 336 & 15 & 409 & 500 & 81,80 \\
\hline & & Total & & & & 4759 & 6000 & 79,32 \\
\hline 13 & \multirow{4}{*}{ 嘉 } & $\begin{array}{l}\text { Keinginan untuk mengikuti program-program seperti double degree, } \\
\text { fullbright, sandwich, dan lain-lain di universitas. }\end{array}$ & 46 & 270 & 13 & 329 & 500 & 65,80 \\
\hline 14 & & Penilaian terhadap universitas ini di tingkat internasional. & 49 & 315 & 14 & 378 & 500 & 75,60 \\
\hline 15 & & Apresiasi anda terhadap universitas ini. & 51 & 327 & 19 & 397 & 500 & 79,40 \\
\hline 16 & & $\begin{array}{l}\text { Kemampuan anda berinteraksi dengan lingkungan sosial dan budaya di } \\
\text { universitas ini. }\end{array}$ & 55 & 326 & 16 & 397 & 500 & 79,40 \\
\hline & & Total & & & & 1501 & 2000 & 75,05 \\
\hline & & Total Skor & & & & 6260 & 8000 & 78.25 \\
\hline
\end{tabular}

(Sumber: Hasil pengolahan data)

\section{Pembahasan Hasil Penelitian}

\subsection{Kualitas Layanan Perguruan Tinggi Negeri di Bandung}

- Competence berkontribusi sebesar 0,59

- Attitude berkontribusi sebesar 0,96

- content sebesar 0,91

- Delivery berkontribusi sebesar 0,91

- Reliability berkontribusi sebesar 0,99

\subsection{Kepuasan Mahasiswa Asing Perguruan Tinggi Negeri di Bandung}

Berdasarkan indeks kepuasan pelanggan yang diperoleh melalui metode Importance Performance Analysis dari hasil tanggapan mahasiswa asing di perguruan tinggi negeri di Bandung diperoleh nilai 79,0102\% yang merupakan termasuk kategori puas yang berarti bahwa kinerja sesuai dengan harapan mahasiswa asing.

Pada kepuasan mahasiswa dimensi tangible memberikan kontribusi yang positif sebesar 0,82, competence sebesar 0,83, attitude sebesar 0,97, content sebesar 0,94, delivery sebesar 0,91, dan reliability sebesar 0,94.

\subsection{Citra Perguruan Tinggi Negeri di Bandung}

Pada citra komponen kognitif memberikan kontribusi yang positif sebesar 0,79 dan afektif sebesar 0,67 .

\subsection{Pengaruh Kualitas Layanan Jasa \\ Pendidikan Terhadap Kepuasan \\ Mahasiswa Serta Dampaknya Terhadap Citra Perguruan Tinggi Negeri di Bandung}

Dengan membandingkan goodness of fit, nilai RMSEA 0,052 $<0,08$, nilai NFI 1,751 $>0,90$, nilai TLI $1,638>0,90$, nilai CFI 1,768 > 0,90, dan nilai CMIN/DF $1,083 \leq 2$ maka diperoleh kesimpulan bahwa semua taksiran parameter adalah signifikan.

Untuk pengaruh kualitas layanan jasa pendidikan terhadap kepuasan mahasiswa asing dinilai positif berpengaruh sebesar 0,87 .

Pengaruh kepuasan mahasiswa asing terhadap citra perguruan tinggi dinilai positif berpengaruh sebesar 0,74 .

Sedangkan pengaruh kualitas layanan jasa pendidikan terhadap citra perguruan tinggi dinilai positif berpengaruh sebesar 0,63.

\section{Kesimpulan}

1. Tanggapan mahasiswa asing terhadap kualitas layanan jasa pendidikan perguruan tinggi negeri di Bandung

a. Kualitas layanan jasa pendidikan di perguruan tinggi negeri di Bandung termasuk kategori baik, berarti bahwa layanan yang diterima atau dirasakan oleh mahasiswa asing sesuai dengan yang diharapkan

b. Kualitas layanan jasa pendidikan dimensi tangible fasilitas kegiatan proses belajar mengajar dan fasilitas perpustakaan dinilai paling baik oleh mahasiswa karena mahasiswa selain mendapatkan teori juga diberikan tempat praktek dan/atau kelompok belajar khusus dan kelengkapan buku di 
perpustakaan serta sistem online nya memudahkan mahasiswa untuk mencari bahan yang diperlukan dengan mudah dimanapun dan kapanpun.

c. Kualitas layanan jasa pendidikan dimensi competence relevansi pengetahuan dan/atau bahan ajar dengan fenomena yang sedang terjadi (up to date) dinilai paling baik karena sesuai dengan perkembangan dan kebutuhan masa depan mahasiswa.

d. Kualitas layanan jasa pendidikan dimensi attitude rasa saling menghormati dan menghargai staf di ITB dinilai paling baik. Sedangkan di UNPAD dan di UPI kerapihan dan kesopanan dosen merupakan sikap yang dapat membuat mahasiswa nyaman dan saling menghargai.

e. Kualitas layanan jasa pendidikan dimensi content ketersediaan pembuatan dokumen mahasiswa asing seperti paspor, visa, asuransi kesehatan, rekening bank, dan police report di ITB dinilai paling baik karena memberikan kemudahan pada mahasiswa asing untuk sekolah dan tinggal di Indonesia. Di UNPAD relevansi kurikulum dengan kebutuhan dan keinginan mahasiswa dinilai paling baik karena UNPAD mendukung dan melaksanakan pendidikan internasional yang memenuhi standar universitas kelas dunia. Sedangkan di UPI relevansi kurikulum dengan kebutuhan dan keinginan mahasiswa dan layanan pembelajaran tugas terstruktur dan/atau mandiri dinilai paling baik karena UPI secara terus menerus memperbaiki kurikulum pendidikannya agar sesuai dengan tuntutan jaman.

f. Kualitas layanan jasa pendidikan dimensi delivery konsistensi penyampaian layanan administrasi di ITB dinilai paling baik karena layanan administrasinya tidak membingungkan mahasiswa dan untuk kelas internasional sistem administrasinya tidak digabung dengan yang reguler. Di UNPAD ketepatan dan keadilan mengevaluasi hasil belajar dinilai paling baik karena dengan ketepatan dan keadilan mengevaluasi hasil belajar maka hasil kerja keras mahasiswa dihargai sehingga mahasiswa tahu tingkat kemampuan dan/atau keahliannya. Sedangkan di UPI konsistensi penyampaian materi perkuliahan dinilai paling baik karena tidak membuat mahasiswa bingung.

g. Kualitas layanan jasa pendidikan dimensi reliability ketepatan menepati janji agar sesuai dengan tujuan di ITB dinilai paling baik karena ITB bisa menyampaikan layanan yang dijanjikan dan menyediakan informasi yang dibutuhkan pada saat diminta. Di UNPAD kemampuan menjaga kepercayaan dinilai paling baik karena para dosen dan staf memiliki pengetahuan, kesopanan dan kemampuan dalam menumbuhkan rasa percaya dan keyakinan mahasiswa. Sedangkan di UPI kemampuan menjaga kepercayaan, ketepatan menepati janii agar sesuai dengan tujuan, dan kemampuan menangani keluhan dan pemecahan masalah dinilai paling baik karena UPI bisa menyampaikan layanan yang dijanjikan dan menyediakan informasi yang dibutuhkan pada saat diminta serta para dosen dan staf memiliki pengetahuan, kesopanan dan kemampuan dalam menumbuhkan rasa percaya dan keyakinan mahasiswa.

2. Tingkat kepuasan mahasiswa asing perguruan tinggi negeri di Bandung

a. Berdasarkan indeks kepuasan pelanggan yang diperoleh melalui metode Importance Performance Analysis dari hasil tanggapan mahasiswa asing di perguruan tinggi negeri di Bandung termasuk kategori puas yang berarti bahwa kinerja sesuai dengan harapan mahasiswa asing.

b. Atribut pelayanan yang harus diprioritaskan atau yang harus mendapat perhatian lebih atau diperbaiki sehingga kinerjanya meningkat antara lain: Asrama mahasiswa, Infrastruktur TI, Fasilitas medism, dan Potensi-potensi staf seperti etos kerja, fleksibilitas, ketelitian, kedisiplinan, kreatif dan inovasi, integritas dan tanggung jawab.

c. Atribut pelayanan yang dikategorikan sebagai atribut yang perlu dipertahankan karena atributatribut inilah yang telah menarik perhatian pelanggan untuk memanfaatkan produk tersebut karena tingkat kepuasan relatif tinggi antara lain: Fasilitas kegiatan proses belajar mengajar (ruang kuliah, laboratorium dan sebagainya), Fasilitas perpustakaan, Kemampuan dosen dalam 
penguasaan bahan ajar secara penuh dan metode pengajaran baik pedagogis dan metodis (Kompetensi profesional dosen), Kemampuan mengajar (Kompetensi pedagogis dosen), Kesopanan dan kerapihan dosen, Rasa tanggung jawab yang besar demi masa depan mahasiswanya, Bersikap sabar dalam mehadapi mahasiswanya tanpa menggunakan emosi dalam bertindak, Saat mengajar dosen berbicara dan/atau bersuara dengan jelas, Menciptakan suasana kelas yang baik, Kesediaan dosen memberikan bimbingan dan saran pada mahasiswa asing, Kesediaan dosen untuk membantu, bergaul dan melayani mahasiswa asing yang berhubungan dengan pekerjaan dosen, Menghormati dan menghargai mahasiswa asing secara wajar dan Ketersediaan pembuatan dokumen mahasiswa asing seperti paspor, visa, asuransi kesehatan, rekening bank, dan police report.

d. Atribut pelayanan yang harus ditingkatkan namun dengan prioritas rendah dalam hal ini adalah: Fasilitas pendukung keagamaan bagi mahasiswa internasional, Kegiatan/organisasi mahasiswa, Fasilitas olahraga, Akomodasi mahasiswa, Rasio perbandingan jumlah dosen dengan mahasiswa asing, Potensi-potensi psikologis dosen untuk tugas-tugas kependidikan, seperti kebutuhan untuk berprestasi, bekerja, berubah, dan otonom (Kompetensi kepribadian), Kemampuan staf bekerja dalam tim, pelayanan prima, berkomunikasi efektif, dan membangun hubungan kerja, Kemampuan menyenangkan mahasiswa asing melalui kesopansantunan yang baik dan kerapihan, Rasa tanggung jawab yang besar dan memberikan keyakinan pada mahasiswa asing atas jasa atau layanan universitas, Berkomunikasi dengan bijaksana dalan melakukan sesuatu dengan benar pada saat yang tepat, Kemampuan staf memahami kebutuhan mahasiswa asing, Kesediaan staf memberikan bimbingan dan saran pada mahasiswa asing, Kesediaan staf untuk membantu, bergaul dan melayani mahasiswa asing yang berhubungan dengan pekerjaan staf, Layanan pembelajaran di luar kelas, Pemantapan, try out, program pamong, dan sebagainya, Layanan administrasi akademik, kemahasiswaan dan keuangan, Ketepatan waktu penyampaian layanan administrasi dan Konsistensi penyampaian layanan administrasi.

e. Atribut pelayanan yang cukup berlebihan karena atribut ini dianggap kurang penting oleh mahasiswa asing namun pada kenyataannya sudah cukup memuaskan antara lain: Rasio kualifikasi dosen S2, S3, Guru Besar atau Profesor, Relevansi pengetahuan dan/atau bahan ajar dengan fenomena yang sedang terjadi (up to date), Rasio perbandingan jumlah staf administrasi dengan mahasiswa asing, Menghormati dan menghargai mahasiswa asing secara wajar, Relevansi kurikulum dengan kebutuhan dan keinginan mahasiswa, Layanan pembelajaran tatap muka, Layanan pembelajaran tugas terstruktur dan/atau mandiri, Ketersediaan layanan kedatangan mahasiswa asing (pick up service) dan kepulangan, Ketepatan waktu penyampaian materi perkuliahan, Konsistensi penyampaian materi perkuliahan, Ketepatan dan keadilan mengevaluasi hasil belajar, Ketepatan/ketelitian dalam setiap layanan yang diberikan, Kemampuan menjaga kepercayaan, Ketepatan menepati janji agar sesuai dengan tujuan, dan Kemampuan menangani keluhan dan pemecahan masalah

3. Tingkat citra perguruan tinggi negeri di Bandung

a. Citra perguruan tinggi negeri di Bandung termasuk kategori positif, berarti bahwa mahasiswa asing memiliki tingkat/derajat seperangkat keyakinan, ide dan kesan yang tinggi atau positif dan berarti pula perguruan tinggi negeri di Bandung dikenal oleh mahasiswa asing.

b. Citra perguruan tinggi negeri ITB berdasarkan komponen kognitif secara keseluruhan bahwa universitas berpengalaman dalam menyelenggarakan program-program internasional merupakan komponen kognitif yang paling mempengaruhi tingkat pembentukan keyakinan, ide dan kesan atau citra positif ITB. Sedangkan berdasarkan komponen afektif, secara keseluruhan bahwa kemampuan mahasiswa berinteraksi dengan lingkungan sosial dan budaya di ITB merupakan komponen afektif yang paling mempengaruhi 
tingkat pembentukan keyakinan, ide dan kesan atau citra positif ITB.

c. Citra mahasiswa asing di UNPAD berdasarkan komponen kognitif secara keseluruhan bahwa memiliki ranking atau peringkat keunggulan dalam bidang khusus merupakan komponen kognitif yang paling mempengaruhi tingkat pembentukan keyakinan, ide dan kesan atau citra positif UNPAD. Sedangkan berdasarkan komponen afektif, secara keseluruhan dapat dijelaskan bahwa apresiasi mahasiswa terhadap UNPAD merupakan komponen afektif yang paling mempengaruhi tingkat pembentukan keyakinan, ide dan kesan atau citra positif UNPAD.

d. Citra mahasiswa asing di UPI berdasarkan komponen kognitif secara keseluruhan dapat dijelaskan bahwa proses belajar mengajar yang ditawarkan sangat baik dan universitas telah dikenal secara internasional dengan baik merupakan komponen kognitif yang mempengaruhi tingkat pembentukan keyakinan, ide dan kesan atau citra positif UPI. Sedangkan berdasarkan komponen afektif, secara keseluruhan dapat dijelaskan bahwa apresiasi mahasiswa terhadap UPI merupakan komponen afektif yang paling mempengaruhi tingkat pembentukan keyakinan, ide dan kesan atau citra positif UPI.

4. Pengaruh kualitas layanan jasa pendidikan terhadap kepuasan mahasiswa asing serta dampaknya terhadap upaya peningkatan citra perguruan tinggi negeri di Bandung. Pengaruh kualitas layanan jasa pendidikan terhadap kepuasan mahasiswa asing dinilai positif berpengaruh sebesar 0,87. Pengaruh kepuasan mahasiswa asing terhadap citra perguruan tinggi dinilai positif berpengaruh sebesar 0,74 dan pengaruh kualitas layanan jasa pendidikan terhadap citra perguruan tinggi dinilai positif berpengaruh sebesar 0,64 .

\section{Rekomendasi}

1. Upaya peningkatan kualitas layanan kemampuan dan/atau keterampilan staf dapat dilakukan dengan pendidikan dan pelatihan terutama untuk bahasa internasional sehingga mahasiswa asing akan semakin puas dengan layanan yang diberikan.
2. Upaya peningkatan citra perguruan tinggi dapat dilakukan dengan tetap menjaga tingkat pengenalan sasaran atas produk dan jasa universitas melalui peningkatan kampanye public relations nya. Sedangkan untuk menjaga citra yang positif secara afektif dapat dilakukan melalui komunikasi yang continue/berkelanjutan.

3. Kekurangan atau kelemahan tesis ini salah satunya adalah jumlah sampel yang berdasarkan perhitungan proposional matematika untuk UPI hanya 4 orang sehingga kurang mewakili. Oleh karena itu, untuk penelitian selanjutnya sampelnya dapat dikaji ulang.

\section{Daftar Pustaka}

Buchari Alma, 2007. Manajemen Pemasaran dan Pemasaran Jasa. Bandung: Alfabeta.

, dan Ratih Hurriyati, 2008. Manajemen Corporate dan Strategi Pemasaran Jasa Pendidikan, Bandung, Alfabeta.

Drost, J. 1990. Untuk Apa Perguruan Tinggi Didirikan, dalam Prisma No. 1 Tahun 1990, Jakarta: LP3ES.

Fandy Tjiptono. 2008. Strategi Pemasaran. Yogyakarta: PT. ANDI Offset.

__. 2008. Service management mewujudkan layanan prima, Yogyakarta: PT. ANDI Offset.

Husein Umar. 2002. Perilaku Konsumen Jasa, Jakarta: Ghalia Indonesia.

2003. Metode Penelitian Bisnis untuk Skripsi dan Tesis Bisnis. Jakarta: PT. Gramedia Pustaka Utama.

Inkeles dan Smith, (1974). Becoming Modern: Individual In Six Developing Countries. Massachusetts: Harvard University Press.

Indrajit, Eko, R dan Djokopranoto, R (2006). Manajemen perguruan Tinggi Modern. Yogyakarta: Andi Offset

Kertajaya, H., 2002. Hermawan Kertajaya on Marketing. Jakarta: PT. Gramedia Pustaka Utama, Jakarta. 
Kotler Philip, Kevin Lane (2009). Manajemen Pemasaran

Edisi Ke 13 jilid 1 dan 2, Jakarta, Erlangga

, and Kevin Lane Keller, 2009. Marketing Management 13th Edition, Pearson International Edition, New Jersey-America.

Parasuraman, A., Valerie Zeithaml, and L.Berry, 1988. Servqual: Multiple Item Scale for Measuring Consumer Perceptions of Service Quality, Journal of Retailing, Vol. 64, p.12-36.

1985. Conceptual Model of Service Quality and its Implication, Journal of Marketing, Vol. 49, Fall, pp. 41-50.

Sugiyono, 2003. Prosedur Penelitian Suatu Pendekatan Praktek, Jakarta: Rineka Cipta.

Sumarto, (2002), Faktor-Faktor Lingkungan Strategik Dalam Pengembangan Perguruan Tinggi SwastaStudi Tentang Faktor-Faktor Lingkungan Perguruan Tinggi Swasta Yang Terakreditasi Di Jawa Barat. Disertasi Doktor pada PPS UPI Bandung, tidak diterbitkan

\section{Jurnal:}

Adee Athiyaman, 1997. Linking Student Satisfaction and Service Quality Perceptions: the Case of University Education, European Journal of Marketing, Vol. 31, No. 7, 1997, pp. 528-540. MCB University Press, 0309-0566.

Asuncion Beerli Palacio, Gonzalo Diaz Meneses and Pedro J Perez, 2002. The Configuration Of The University Image And Its Relationship With The Satisfaction Of Students, Journal of educational admninistration, Vol. 40, No. 5, pp. 486-505. MCB UP Limited, 0957-8234.

Corneliu Munteanu, Ciprian Ceobanu, Claudia Bobâlca and Oana Anton, 2010. An Analysis of Customer Satisfaction in a Higher Education Context, International Journal of Public Sector Management Vol. 23, No. 2, 2010, pp. 124-140. Emerald
Group Publishing Limited 0951-3558 DOI 10.1108/09513551011022483.

Helena Alves and Ma'rio Raposo, 2010. The Influence of University Image on Student Behaviour, International Journal of Educational Management Vol. 24, No. 1, 2010. pp. 73-85. Emerald Group Publishing Limited 0951-354X DOl 10.1108/09513541011013060.

Mohammad S Owlia and Elaine M Aspinwall, 1996. a Framework for the Dimension of Quality in Higher Education, Quality Assurance in Education Volume 4, Number 2, 1996. pp. 12-20. MCB University Press, ISSN 0968-4883. 